\title{
Industrial Development in the EU: Lessons for the Future Member States?
}

\author{
Mirella Damiani \\ University of Perugia, Department of Economics, Finance and \\ Statistics, Italy \\ mirelladamiani@libero.it

\section{Milica Uvalic} \\ University of Perugia, Department of Economics, Finance and \\ Statistics, Italy \\ milica.uvalic@unipg.it
}

\author{
CroEconSur \\ Vol. 16 \\ No. 1 \\ May 2014 \\ pp. 5-48
}

Received: December 11, 2013

Accepted: March 3, 2014

Professional Article

doi:10.15179/ces.16.1.1

\section{Abstract}

The paper analyzes the main characteristics and major changes in manufacturing industry in the old EU member states over the past twenty years, in order to draw some lessons for the Southeast European economies in transition, often referred to as the Western Balkans (WBs) - Albania, Bosnia and Herzegovina, Croatia, Kosovo, Macedonia, Montenegro and Serbia. During the last twenty years the more developed EU member states have experienced substantial changes in the structure of their economies, with services becoming the prevalent sector in terms of the most important indicators. Nevertheless, there is great heterogeneity within the EU regarding the contribution of manufacturing to employment and value added. The global financial and economic crisis from late 2008 onwards has revived the debate about the role of industry, its importance for economic growth and for international competitiveness. In this context, there has also been a renewed interest in industrial policy and reindustrialization. The ongoing analysis of trends in the EU could be extremely relevant for the WB countries, since these 
countries have gone through a process of strong deindustrialization. Given that their level of economic development is still low, manufacturing industry remains indispensable for future economic growth. The EU experience could offer useful guidelines for formulating future policies in this area.

Keywords: industrial development, structural changes, industrialization, Western Balkans

JEL classification: O14, L60, P20

\section{Introduction'}

The paper analyzes the main characteristics of manufacturing industry in the European Union (EU) member states, with the aim of drawing some main lessons for the Southeast European economies in transition - Albania, Bosnia and Herzegovina, Croatia, Kosovo, Macedonia, Montenegro and Serbia, frequently referred to as the Western Balkans (WBs). Croatia was the first from this group of countries to join the EU, on 1 July 2013, when it became the 28th EU member state. The other countries are also aspiring to become EU members over the coming years, so the experience in industrial development of the more developed EU countries could prove useful.

The global financial and economic crisis has had a profound impact on most European economies from late 2008 onwards. The economic crisis has proved to last much longer than was initially expected, while the sovereign debt crisis in the eurozone has in the meantime added further worries to an already troubled European Economic and Monetary Union. The unexpected prolongation of the recession in a number of EU countries and the uncertain prospects of permanent economic recovery have also brought very different proposals of economists worldwide regarding the right recipes. These developments have revived the debate

1 An earlier version of the paper was presented at the international conference "The Role of Europe's Industry in the 21st Century", organized by The Institute of Economics, Zagreb, November 21, 2013 in Zagreb, Croatia. The authors would like to thank the discussants and other participants of the conference for their comments, as well as two anonymous referees for useful suggestions in revising the paper. 
about the role of manufacturing industry, its importance for economic growth and for international competitiveness. The European Commission has proposed to increase the share of manufacturing value added from 16 to 20 percent of GDP by 2020 (European Commission, 2012), while in its latest Competitiveness Report it suggests to raise EU competitiveness through "knowledge-driven reindustrialization" (European Commission, 2013). The recent Bruegel study on Europe's manufacturing (Veugelers, 2013) also confirms the increasing relevance of these topics. Although the role of industrial policy remains controversial, the debate points to the importance of policy-induced measures for strenghthening competitiveness. Today these issues are extremely important for EU countries, but are even more important for the WBs, given that their level of development is still low, export performance is unsatisfactory and competitiveness on world markets is insufficient (Uvalic, 2013b).

The paper is structured as follows. In the next section, some of the main features of the evolution of the industrial structure in the EU member states will be analyzed, including changes in the contribution of manufacturing employment and value added, intra-industry sectoral specialization and internationalization of EU manufacturing. The most important characteristics of the WB economies are briefly recalled in Section 3, in order to show why the ongoing debate on reindustrialization in Europe is highly relevant for these countries. Main policy recommendations for the WBs are given in Section 4, before drawing a few concluding remarks in Section 5.

\section{The Changing Industrial Structure in the EU}

During the last twenty years the more developed EU member states have experienced substantial changes in the structure of their economies, characterized by a reduction in the share of manufacturing value added and employment, along with services becoming the prevalent sector. Nevertheless, it should be stressed that the two sectors have become increasingly complementary. There are a 
number of industry-supporting services, such as product design, marketing, ICT supporting activities or assembling, that are important inputs for manufacturing production. At the same time, manufacturing has a carrier function for services, since services generally have limited tradability (European Commission, 2013: $10)$.

Despite the broad patterns of structural change towards a decline in the role of manufacturing industry, there is great heterogeneity within the EU, even among the old EU member states, regarding the contribution of manufacturing to employment and value added and the most competitive sectors. We will present the main features and changes that have taken place in manufacturing industry over the past two decades in the old EU member states, but occasionally also in the US as their main competitor. ${ }^{2}$

\subsection{Trends in Manufacturing Employment and Value Added}

The share of manufacturing employment has declined substantially from the 1970s until the early 2000s, as widely documented by Pilat et al. (2006) for all OECD countries. This decline has also been recorded throughout the 1990-2007 period in both the EU-13 $33^{3}$ and the US, although there are notable differences between the two regions. In the US, the share in manufacturing employment went down from 15 percent in 1990 to a low 10 percent of total employment in 2007, whereas in the EU-13 it declined from over 20 percent in 1990 to 15 percent in 2007 (OECD, 2014a). EU countries in 2007, therefore, had a share of manufacturing employment corresponding to the level that the US had seventeen years earlier (in 1990).

However, within the EU, there are important cross-country differences. Among the economies with the highest drop in manufacturing employment one finds

2 The analysis will cover mainly the period from 1990 to 2007 for two reasons: first, we wanted to get an insight into longer-term trends in the EU under "normal" conditions, before the outbreak of the global economic crisis; second, the main source of our data, OECD (2014a), does not cover all EU countries after 2006-2007.

3 Greece and Protugal are not included because of lack of data in OECD (2014a). 
Germany, where the share of manufacturing employment fell by approximately 9 percentage points, from 28.3 percent in 1990 to 19.0 percent in 2007 (OECD, 2014a). Despite this decline, in 2007 Germany still had the second highest share in manufacturing employment after Italy (20.1 percent), whereas the US was the country with the lowest share (9.9 percent). Over the 1990-2007 period, Germany was the country that had the most remarkable decline in the share of manufacturing employment (9 percentage points), while Finland the least (less than 3 percentage points) (see Figure 1).

Figure 1: Share of Manufacturing in Total Employment

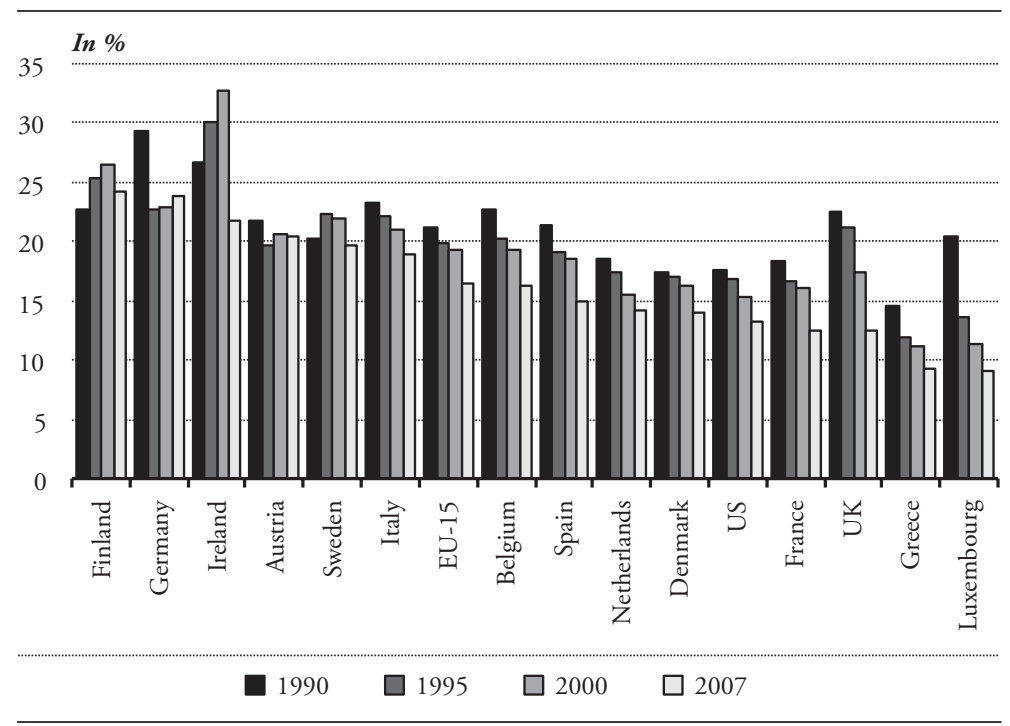

Source: Authors' elaboration based on OECD (2014a).

In most countries, the underlying cause of the decline of manufacturing employment shares was not only the increase of employment in services, but also the loss in absolute values of employees working in manufacturing; the only exception is Spain, which actually increased the number of employees by 15 percent during the 1991-2007 period. ${ }^{4}$ The UK is the country that accounts for 4 In this country, the high growth of employment in services essentially caused the decline of the manufacturing share. 
the largest percentage drop in the absolute value of employees in manufacturing (-33.3 percent) between 1991 and 2007 (OECD, 2014a).

Looking further into manufacturing employment from 1990 onwards, we can again note huge and persistent differences between the EU-13 and the US (see Figure 2). Among the EU countries, Germany registered a very steep decline in manufacturing employment in the early 1990s after the reunification of the country, but other countries - including Italy, the UK and France - also experienced similar, though less marked changes.

Figure 2: Share of Manufacturing in Total Employment in Some EU Countries and the US

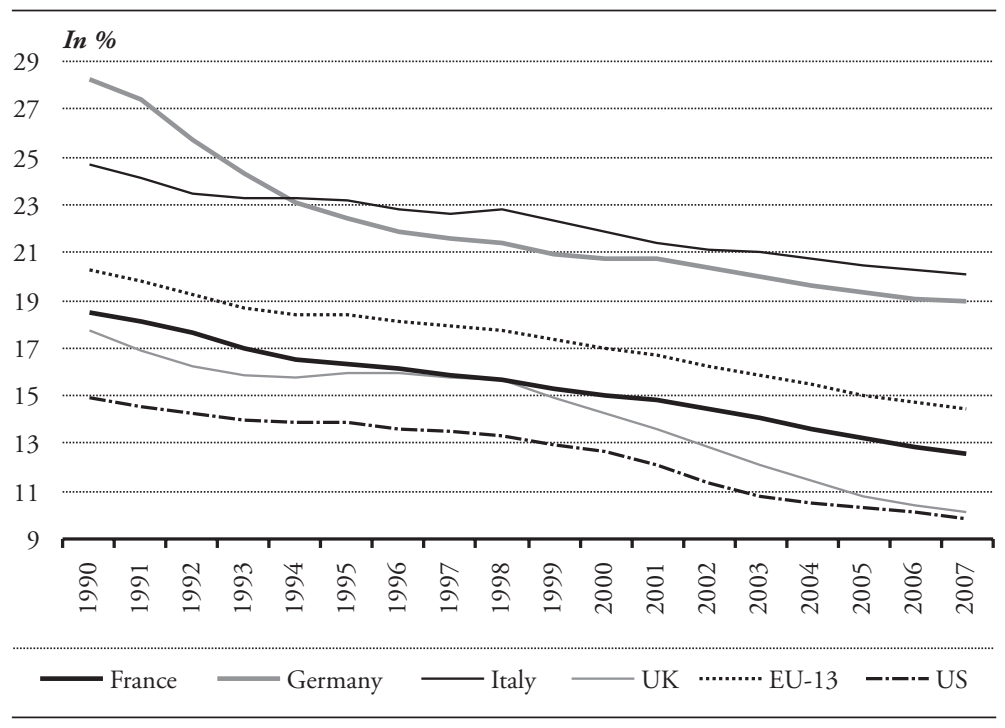

Source: Authors' elaboration based on OECD (2014a).

Recent patterns in manufacturing employment also reflect significant shifts of production. If we consider the other key indicator, the contribution of manufacturing to value added available for more countries in the OECD database (OECD, 2014a), all data confirm previous findings concerning the declining role of manufacturing. From 1990 to 2007, the largest fall in the share 
of manufacturing value added occurred in Luxembourg (from over 20 to around 9 percent) and the UK (from over 22 to around 12 percent), while the lowest was recorded in Sweden where the decline was minimal (from 20.4 to 20.0 percent). Over the same period, Germany registered a decline of approximately five percentage points, lower than that observed in its employment manufacturing share, but in 2007 the share of manufacturing value added was still as high as 23.6 percent, the highest among EU-15. These different patterns of employment and value added observed in Germany clearly reflect the modification of industrial relations of the mid-1990s and various labor market reforms (Carlin, 2012; Bonatti and Fracasso, 2013).

Despite these changes, in 2007 Germany still occupied a leading position among the EU economies with its manufacturing sector representing almost 25 percent of its total value added. An important driving force of Germany's performance is its high R\&D expenditure, the highest among the most important EU economies (see Figure 3).

Figure 3: R\&D Expenditure (2005 US Dollars - Constant Prices and PPPS)

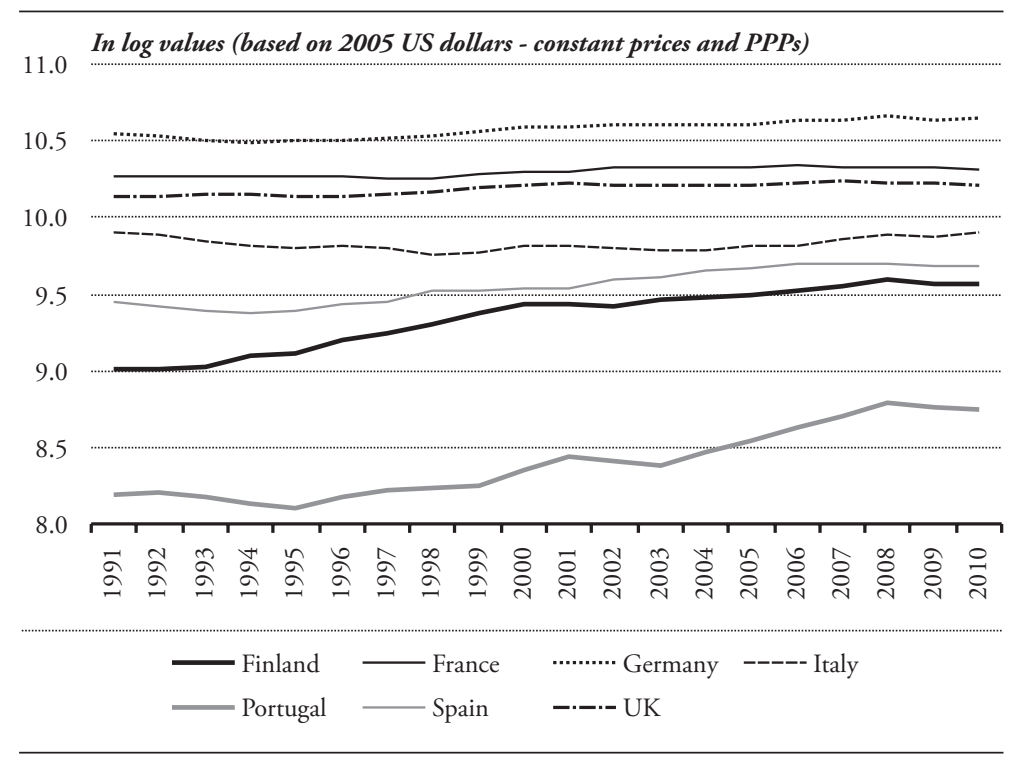

Source: Authors' elaboration based on $\operatorname{OECD(2014a).~}$ 
Along with R\&D, another possible cause of the efficiency gap among EU countries as well as the $\mathrm{EU}$ and its major global partners is the excessive regulation of product markets. The limited degree of competition does not assure adequate incentives for individual firms to adopt the best strategies. This is because product market competition is a key factor influencing aggregate performance indicators such as productivity (Nicoletti and Scarpetta, 2003). Furthermore, as shown by the comparative analysis of Bartelsman, Haltiwanger and Scarpetta (2013) that covers five developed economies and three transition economies from Eastern Europe, excessive regulation can cause distortions due to misallocation of resources. The experience of the centrally-planned economies suggests that in countries characterised by widespread market- and policy-induced distortions, the largest businesses are not necessarily the most productive ones, but rather those that receive preferential treatment (Bartelsman, Haltiwanger and Scarpetta, 2013).

If we now consider the changes in the shares of both manufacturing employment and manufacturing value added in 2007 and compare them with the situation in 1990, we find a variety of patterns (Figure 4).

Interestingly, in Luxembourg, the UK and Spain, losses in the share of manufacturing employment were smaller than the decline in manufacturing value added. In Belgium, France and Italy, and somewhat less in the US, the reduction in manufacturing employment and in value added were of similar magnitudes. In the Netherlands, Ireland, Germany, Denmark, Austria, Sweden and Finland, huge falls in manufacturing employment were not accompanied by as pronounced changes in value added, which were much more modest. Finland was the only country that, over the considered period, experienced an increase in the share of manufacturing value added simultaneously with a decline in manufacturing employment (see Figure 4). 
Figure 4: Changes of Shares in Manufacturing Employment and Value Added in Some EU Countries and the US Over the 1990-2007 Period

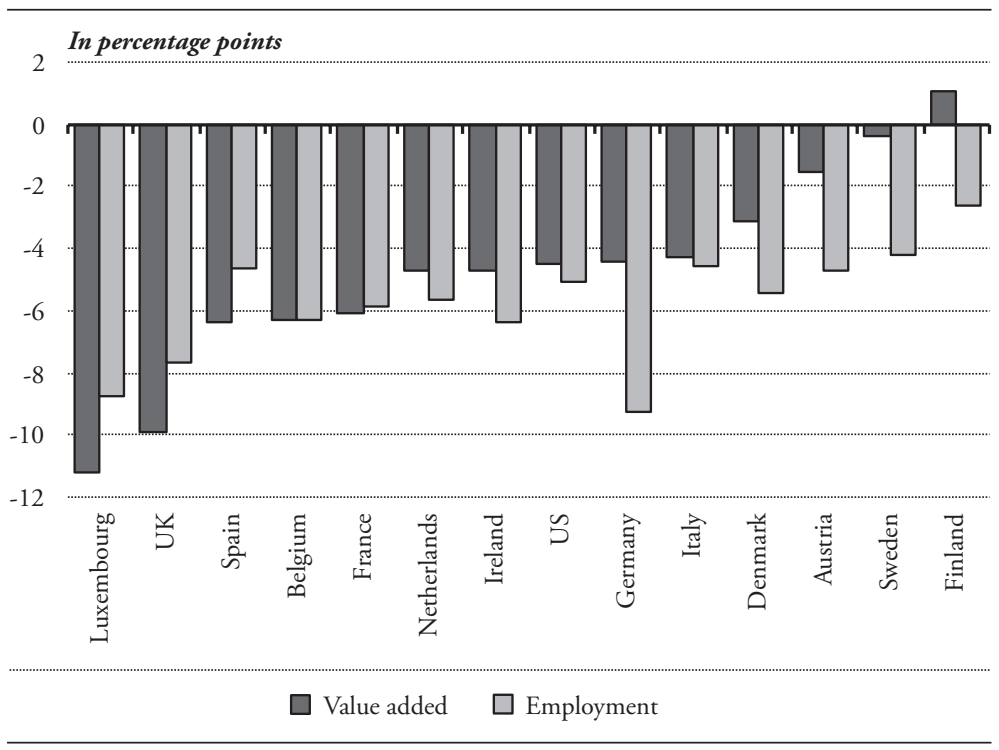

Source: Authors' elaboration based on OECD (2014a).

In 2007, Finland held the first position among EU countries, with a share of 24.2 percent of manufacturing value added, closely followed by Germany and somewhat less by Ireland, Austria, Sweden and Italy. For the EU-14 group (Portugal excluded), the average manufacturing value added in 2007 was substantially lower (16.5 percent), only slightly higher than for the US (13.2 percent $)^{5}$ (see Figure 5). It is interesting to note that the changes in manufacturing value added were not unidirectional in all EU countries. While most countries followed the pattern of declining manufacturing value added over the eighteenyear period, Finland and Ireland initially, during 1990-2000, experienced an increase in manufacturing value added, followed by a decline only after 2000 .

5 Countries presented in Figure 4 are only those for which data were available both for employment and value added in the years considered. 


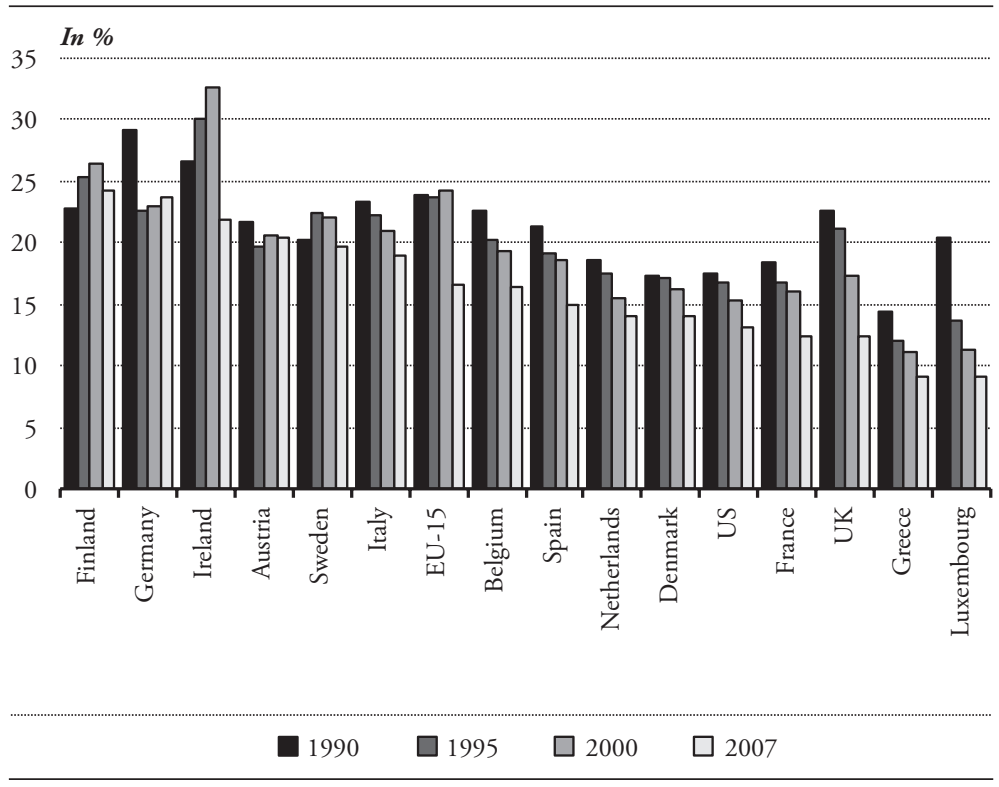

Source: Authors' elaboration based on OECD (2014a).

The ongoing analysis of manufacturing employment and value added over the 1990-2007 period leads to some important conclusions.

First, observing temporal changes, we find that Germany experienced the largest drop of manufacturing in terms of employment, but much less in terms of value added, which in 2007 was still relatively high, close to 25 percent.

Second, the general trend of declining relative importance of manufacturing was associated with losses in absolute levels of employment, which were recorded in all EU countries except Spain.

Third, three EU economies should be singled out for the importance of manufacturing in 2007 (the last year considered): Finland had the highest relative 
share in manufacturing value added, followed by Germany, while Italy had the highest share in manufacturing employment, followed again by Germany.

Comparing the EU with the US, we find substantial differences. In the US, in 2007, only 10 percent of the workforce was engaged in manufacturing (as compared to the average for the EU-14 of 14 percent), while the share of manufacturing value added was rather low, close to 13 percent (as compared to the EU-14 average of 16.7 percent).

\subsection{Changes Within Manufacturing Sectors}

It is also important to examine whether cross-country differences in EU manufacturing, illustrated in the previous section, are accompanied by diversities within the manufacturing sector. During the 1990-2006 period, we observed considerable variations across subsectors. The most notable decline in employment shares within manufacturing occurred in textiles (from 12.6 in 1990 to 7.2 percent in 2006), whereas for chemicals the opposite trend towards increase was recorded (from 9.9 percent in 1990 to 11.1 percent in 2006). These opposite tendencies of employment in textiles and chemicals were already observed for the period until the early 2000s by Pilat et al. (2006).

If we further consider trends in shares of manufacturing employment by key sectors during the 1990-2006 period, we can note that one of the largest sectors, machinery and equipment, increased its relative share (see Figure 6). A slight increase has been recorded also in food, basic metals and transport equipment. In other subsectors, such as wood, paper products and other manufacturing, the employment share has been relatively stable, while in non-metallic minerals it has declined slightly. Therefore, some sectors did register an increase of their relative share over the 1990-2006 period, while only textiles registered a notable fall. 
Figure 6: Manufacturing Employment by Key Sectors in the EU

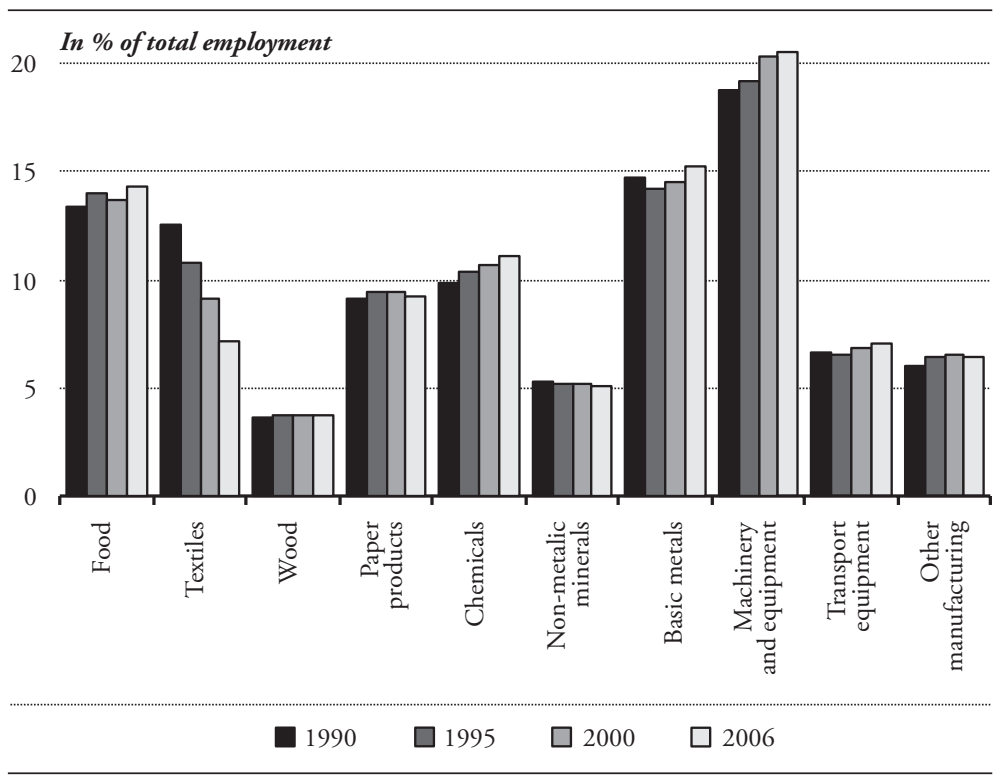

Source: Authors' elaboration based on OECD (2014a).

Statistics on the share of manufacturing value added by key subsectors during the same period confirm these findings (see Figure 7). If we consider the changes in manufacturing value added by sector over the 1990-2006 period, we note that the shares of some sectors have increased, including chemicals, machinery and equipment, and somewhat less food and transport equipment. At the same time, there was a strong fall in textiles.

The OECD database makes available information on different manufacturing activities classified by Eurostat according to R\&D intensities ( $R \& D$ expenditure as a share of sales) and based on NACE Rev. 1.1 at 3-digit levels. Four different groups are given: i) high-tech sectors, i.e. the knowledge based industries, such as pharmaceuticals, aerospace and advanced electronics; ii) medium-high-tech sectors, such as chemicals, cars, and other engineering industries; iii) medium- 
low-tech industries such as fuels, basic metals and mineral products; and iv) lowtech manufacturing, including food, textiles, wood and paper products.

Figure 7: Manufacturing Value Added by Key Sectors in EU-15 (in \% of total value added)

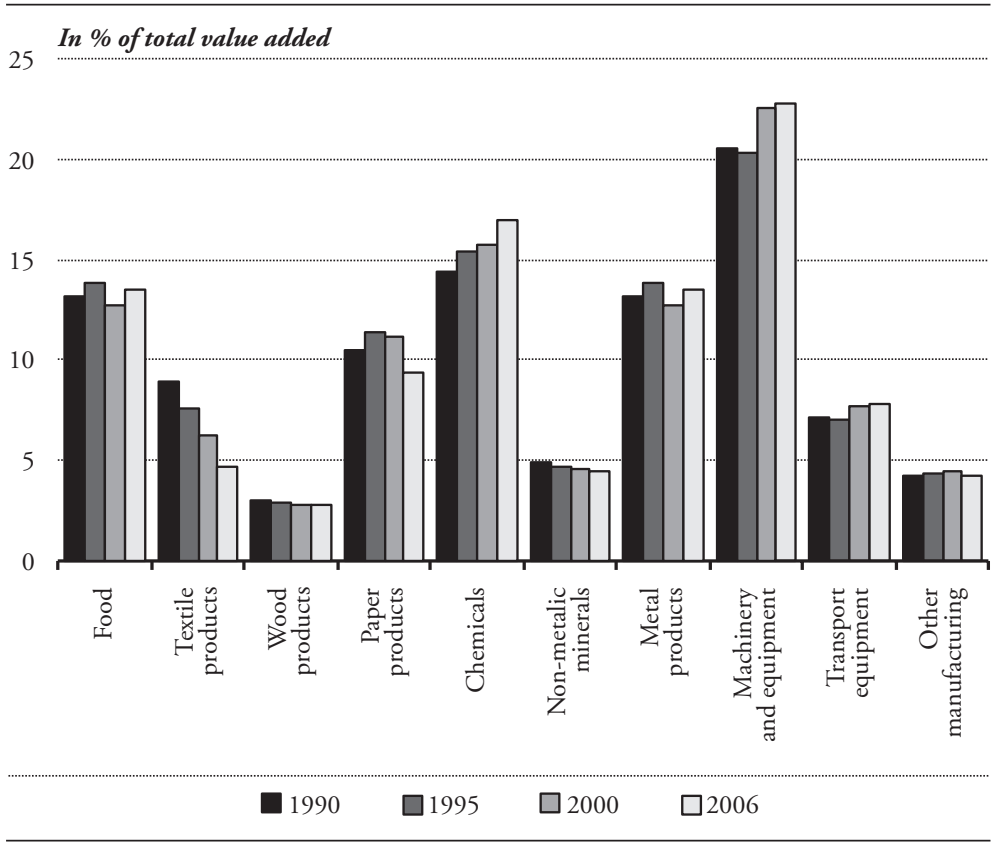

Source: Authors' elaboration based on OECD (2014a).

A comparison of the EU countries and the US in high-tech manufacturing employment (Figure 8) and the respective shares of manufacturing value added (Figure 9) illustrates well the persistent advantage of the US held throughout the observed period, although there are clear signs of EU's catching up. 
Figure 8: Employment Shares in Manufacturing of High-tech Sectors in Some EU Countries and the US

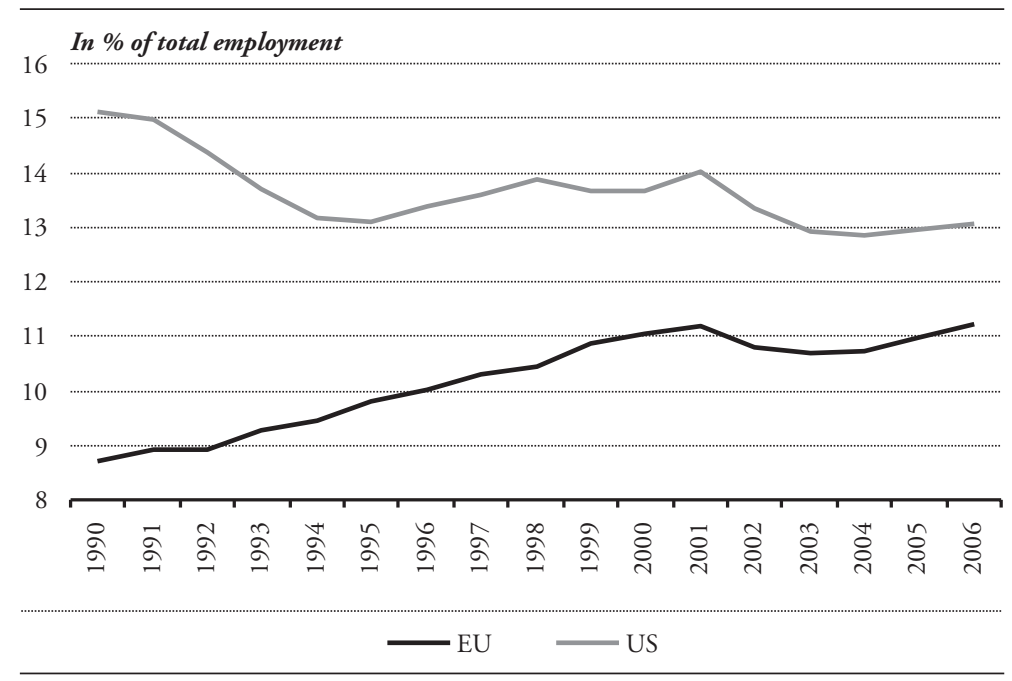

Source: Authors' elaboration based on OECD (2014a); EU data refer to Austria, Denmark, Finland, France, Germany, Ireland, Italy, Spain, and Sweden.

Figure 9: Value Added Shares in Manufacturing of High-tech Sectors in Some EU Countries and the US

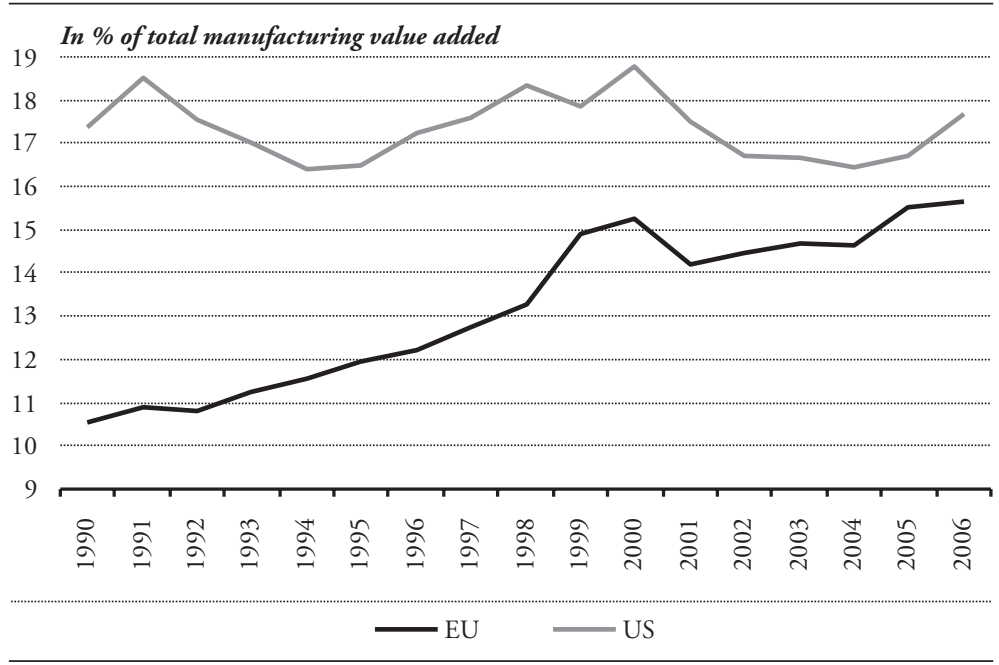

Source: Authors' elaboration based on OECD (2014a); EU data refer to: Austria, Denmark, Finland, France, Germany, Ireland, Italy, Spain, and Sweden. 
Within the EU, we observe great differences regarding the role of high-tech sectors between the two main manufacturing leaders, namely Germany, where knowledge-based industries have had an increasing importance, and Italy, where the 2000s were characterized by just the opposite trend (see Figure 10). Note also that in France the value added share in manufacturing of high-tech sectors is increasing over the whole period and is approaching the values recorded in the US and the UK.

Figure 10: Value Added Shares in Manufacturing of High-tech Sectors

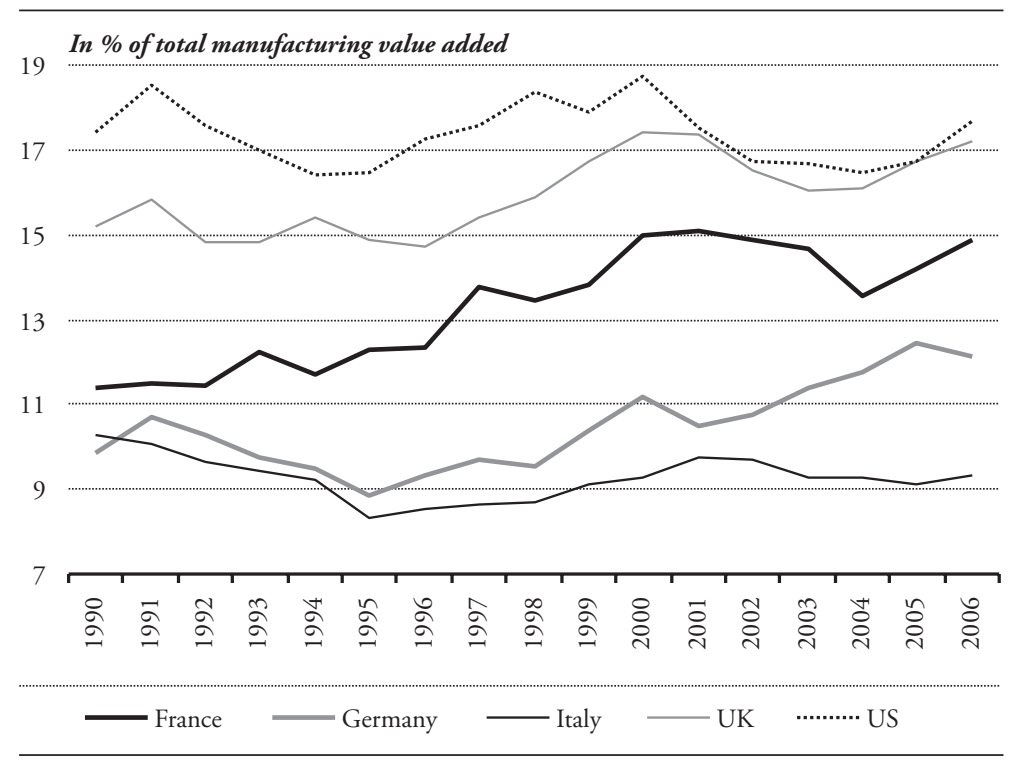

Source: Authors' elaboration based on OECD (2014a).

Regarding medium high-tech sectors (see Figure 11), there are striking differences between Germany and Italy in two key sectors, namely chemicals and transport equipment, since the two countries have registered opposite trends. The comparative advantage of Germany in medium-high-tech sectors is clear from Figures 11 and 12. Statistical information gathered by the OECD database confirm that Germany tended to strengthen its international competitiveness 
in the production of capital goods, pharmaceutical and consumer durables in which it traditionally enjoyed a comparative advantage (Bonatti and Fracasso, 2013; see also Coricelli and Wörgötter, 2012). On the contrary, in Italy the shares of value added of chemicals and transport equipment have been relatively stable or declining; only in machinery and equipment has the value added share slightly increased.

Figure 11: Medium-high-tech Manufacturing Sectors

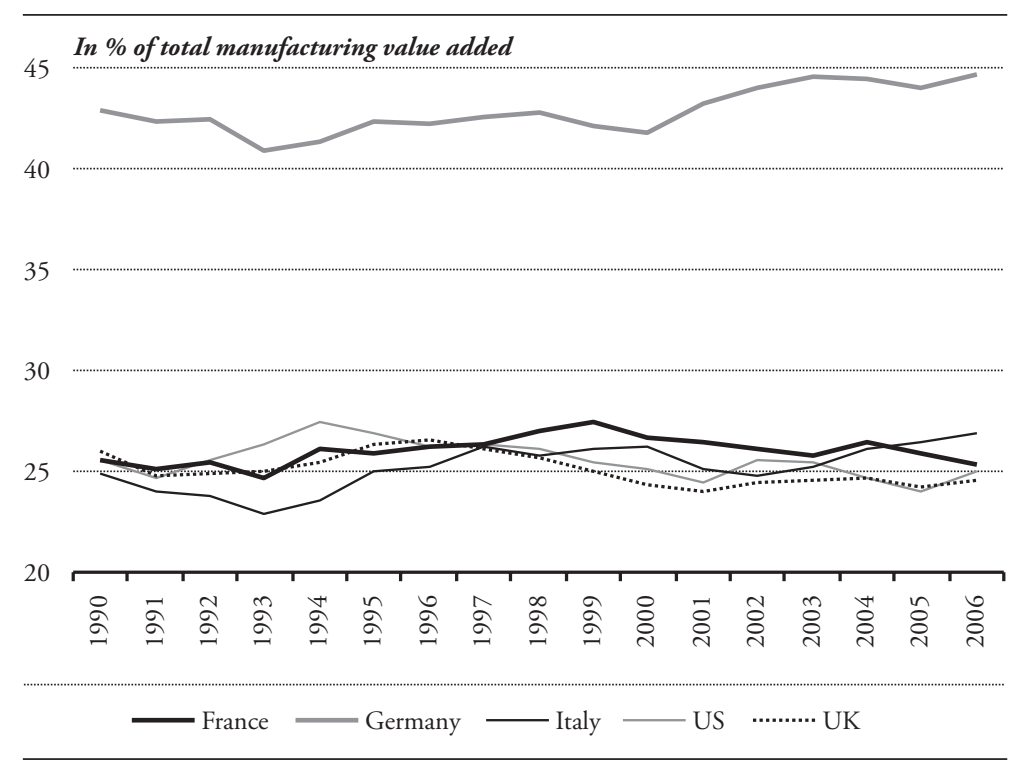

Source: Authors' elaboration based on OECD (2014a). 
Figure 12: Value Added Shares of Medium-high-tech Sectors in Germany and Italy
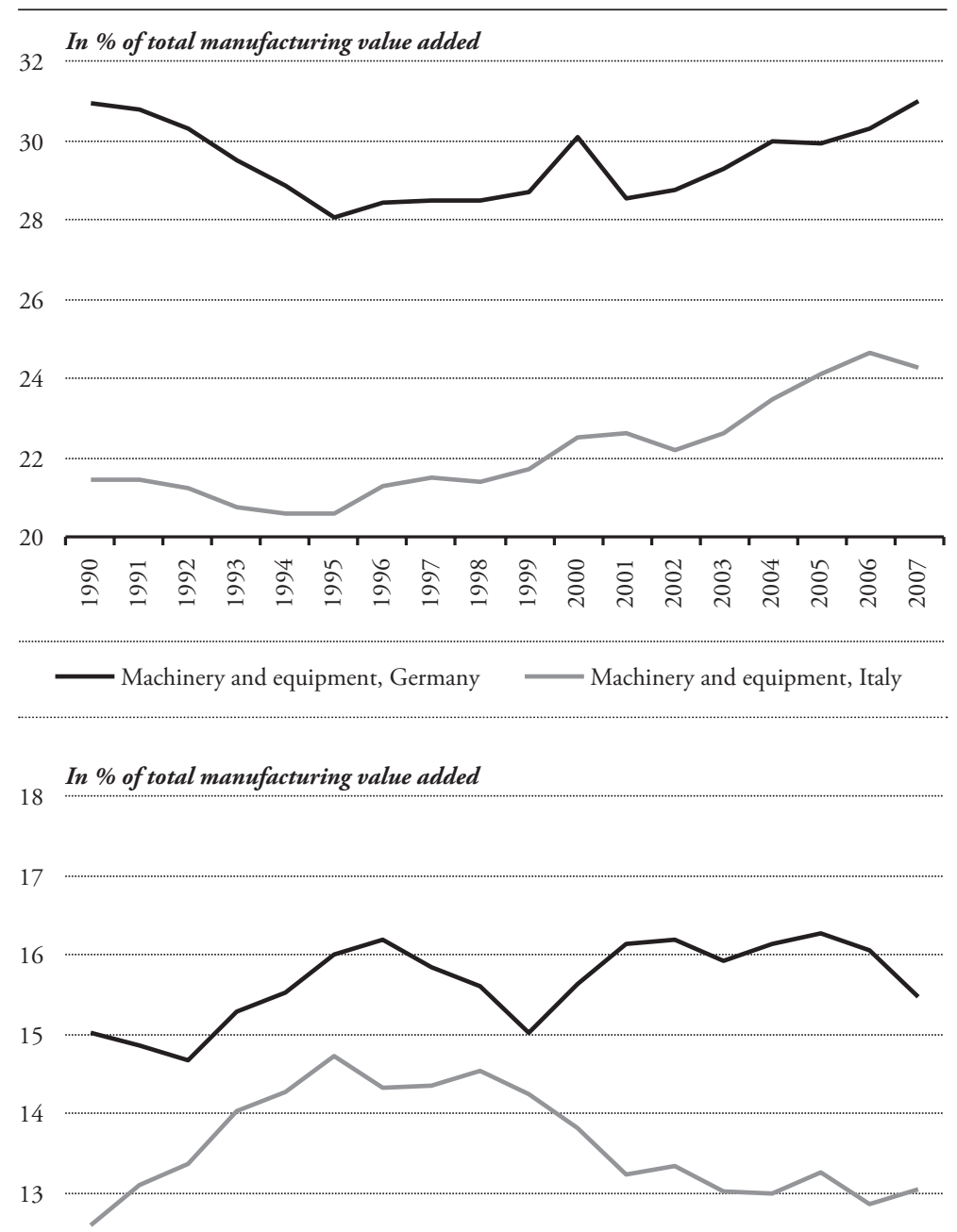

12

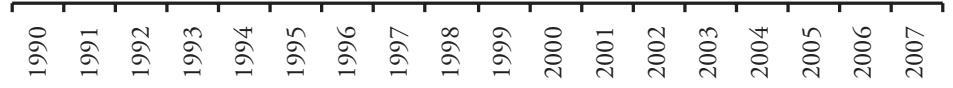




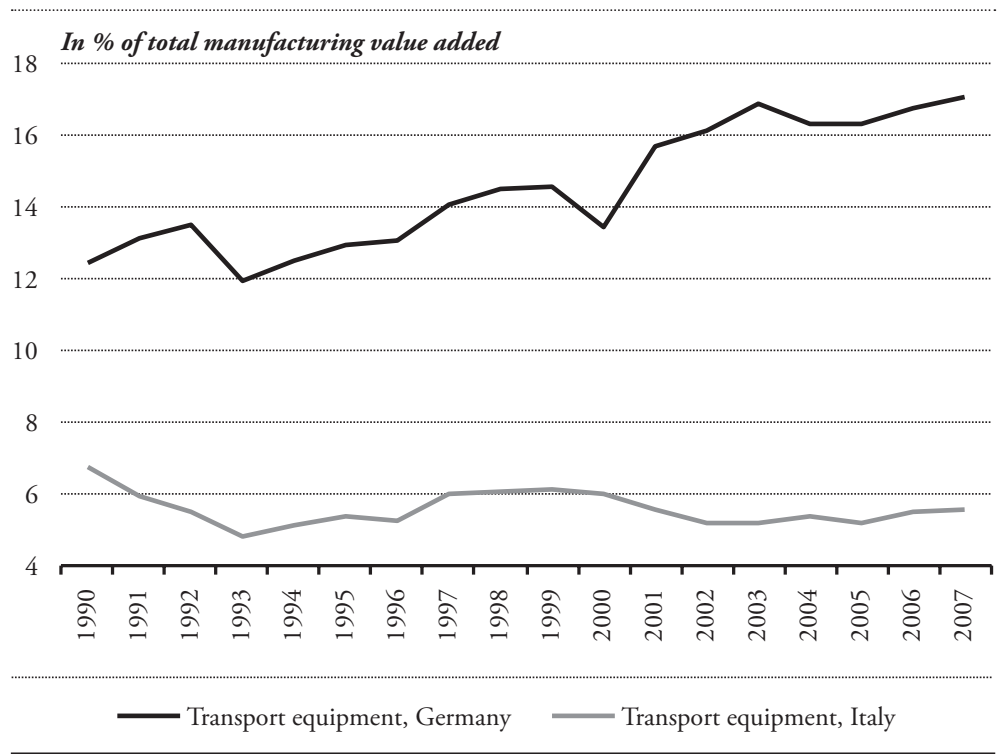

Source: Authors' elaboration based on $\operatorname{OECD}(2014 \mathrm{a})$.

\subsection{Internationalisation of Manufacturing}

The growing orientation of manufacturing production towards foreign markets is a widespread phenomenon in the EU and the US from the 1990s onwards, as evidenced by increasing shares of manufacturing exports (see Figure 13). These trends confirm that the growth of international trade has been faster than that recorded in manufacturing production. For some countries, however, such as Belgium and the Netherlands, the high values are mainly caused by re-exports of imported goods (Pilat et al. 2006). ${ }^{6}$

The trend in internationalization of manufacturing is extremely variable among the EU member states and with respect to the US (see Figure 14).

6 Recent research indicates that as much as 40 percent of total exports in the Netherlands should be considered as re-exports of imported goods, without being significantly processed; see Pilat et al. (2006: 16). 
Figure 13: Share of Exports in Manufacturing Production in Some EU Countries and the US

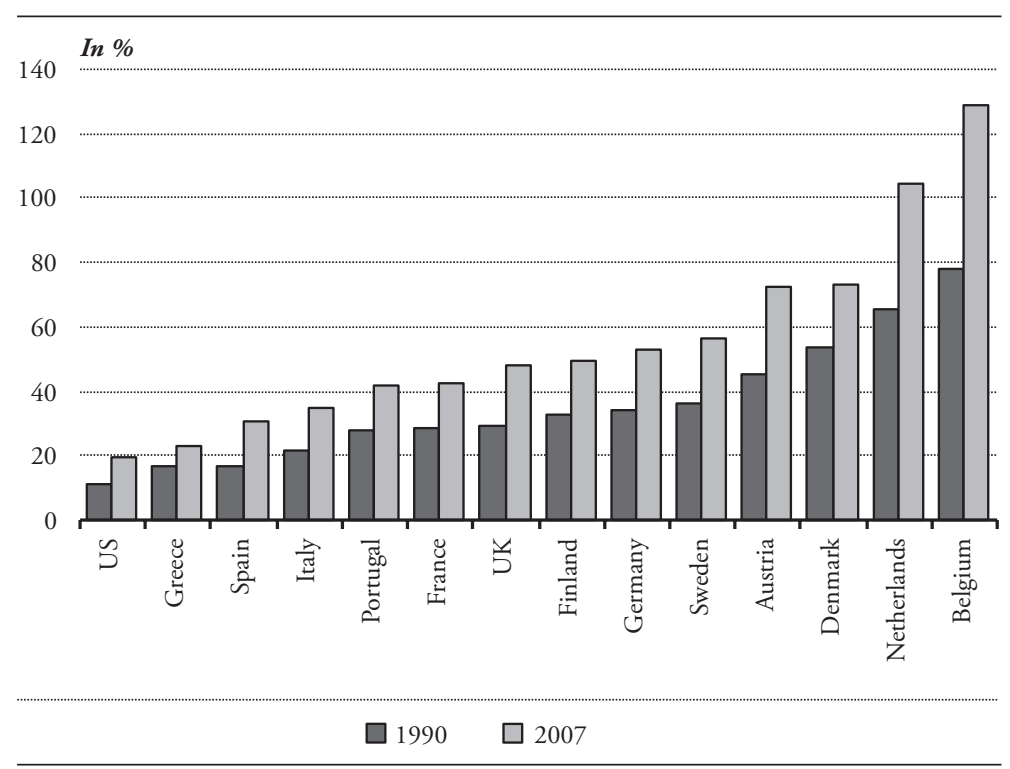

Source: Authors' elaboration based on OECD (2014a); data for Portugal, Sweden, and the UK refer to 2006.

Figure 14: Export Market Shares of Manufacturing Relative to the World

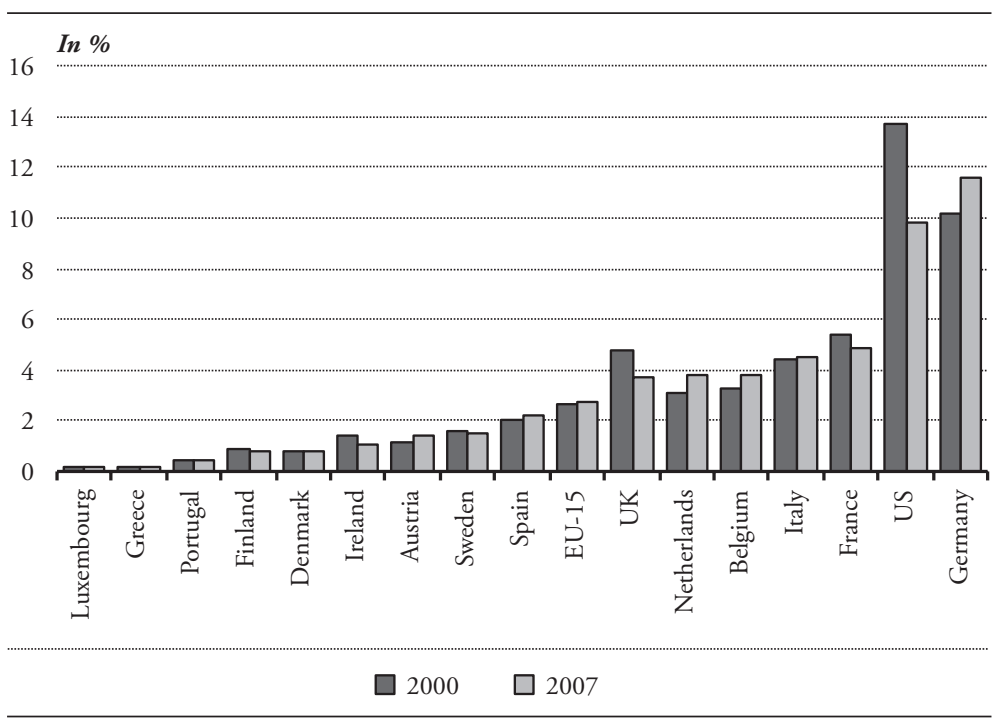

Source: Authors' elaboration based on OECD (2014a). 
The two main global players in manufacturing in 2000, the US and Germany, occupied top positions also in 2007. However, over the 2000-2007 period, the market share of Germany has increased, while that of the US has declined, so there was a reversal of their relative positions. Other countries that have experienced a decline in their market shares are the UK and France, but these countries nevertheless remain with values above the average for the EU-15 (see Figure 14). The increasing share of export market shares of Germany is particularly significant, because it occurred in a global scenario in which the EU-15 has recorded a stable trend, while on average, over the whole period, there has been a fall in export shares of around 10 and 5 percentage points for the G-7 and all OECD countries, respectively (OECD, 2014a).

Another way of assessing the relative strength of different countries in international trade is to compute the Relative Comparative Advantage (RCA) indicator.7 Recent OECD data (OECD, 2014b) show that in 2009 the EU-15 had a comparative advantage in food, wood and paper products, chemicals, basic metals and machinery (see Figure 15). The US also shows a comparative advantage in wood and paper products, similar to the EU-15, a weak specialization in chemicals and non-metalic mineral products, but a stronger specialization in transport equipment. China has clearly become strongly specialized in textiles and electric and optical equipment.

Changes in specialization over the 2005-2009 period for the EU-15 should also be considered (see Figure 16; values above/below the x-axis reveal specialization/ de-specialization).

7 The RCA index is defined as the ratio of a country's exports in a given sector in its total exports, and the share of world exports of the same sector in total world exports. A county's RCA index is equal or lower than one in the case of no specialization, while it is higher than one in the case of specialization. 
Figure 15: Revealed Comparative Advantage in Manufacturing Sectors, 2009

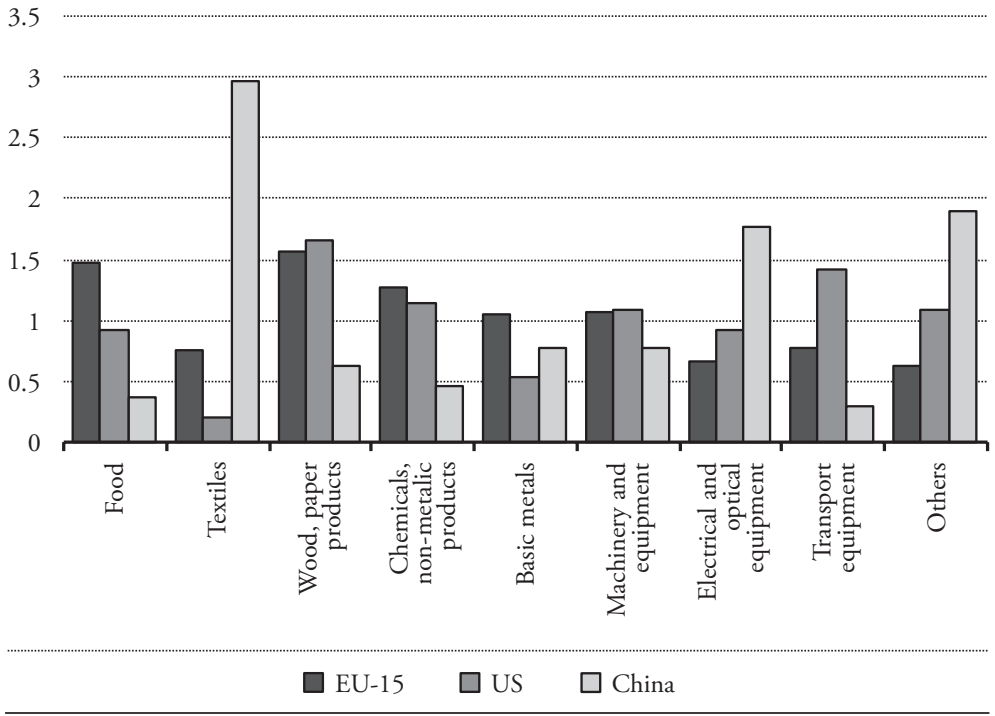

Source: Authors' elaboration based on OECD (2014b).

Figure 16: Revealed Comparative Advantage in Manufacturing Sectors, EU-15

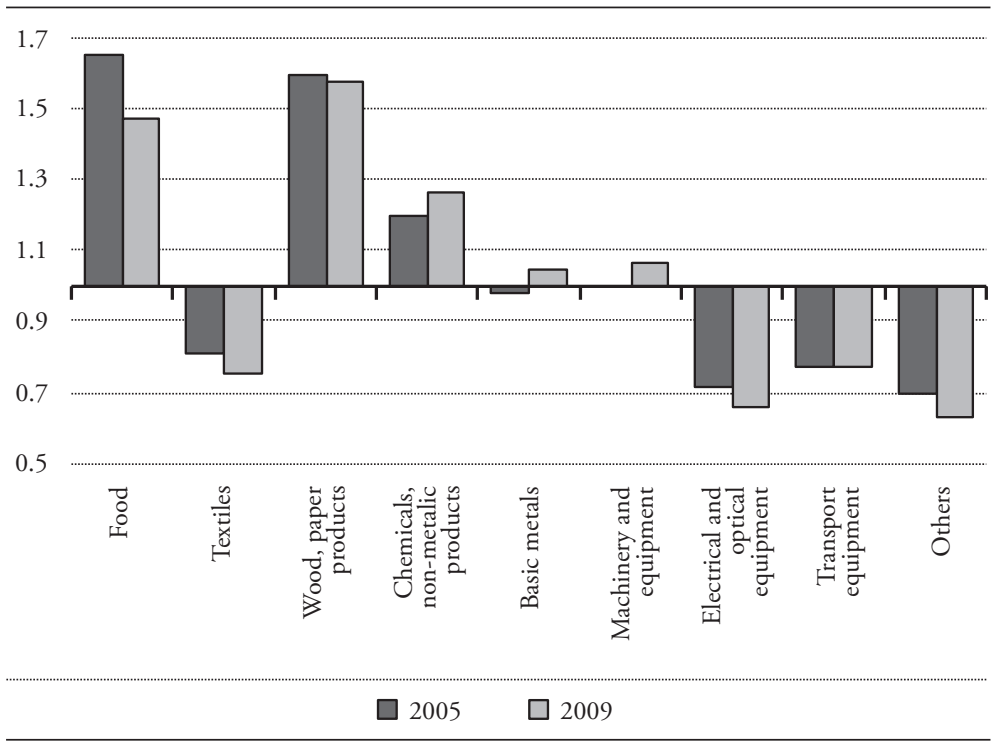

Source: Authors' elaboration based on OECD (2014b). 
During the 2005-2009 period, the EU-15 reduced its comparative advantage in food, as well as in wood and paper products. In addition, by 2009 they were more de-specialized in textiles, electrical and optical equipment and other manufacturing with respect to 2005. On the contrary, the EU-15 increased its specialization in chemicals and, slightly, in basic metals and machinery and equipment.

An analysis of export market shares of manufacturing in the EU-15 and the US by type of technology during the 2000-2007 period shows additional interesting results. In high-tech sectors, the US holds the first (but declining) position in exports relative to the world, followed by Germany that has increased its market share, suggesting a clear catching-up process (see Figure 17). Other EU countries with a significant export share in world high-tech manufacturing include Netherlands, France, the UK and Belgium (all above the average value recorded in the EU-15).

Figure 17: Export Market Shares of High-tech Manufacturing Relative to the World

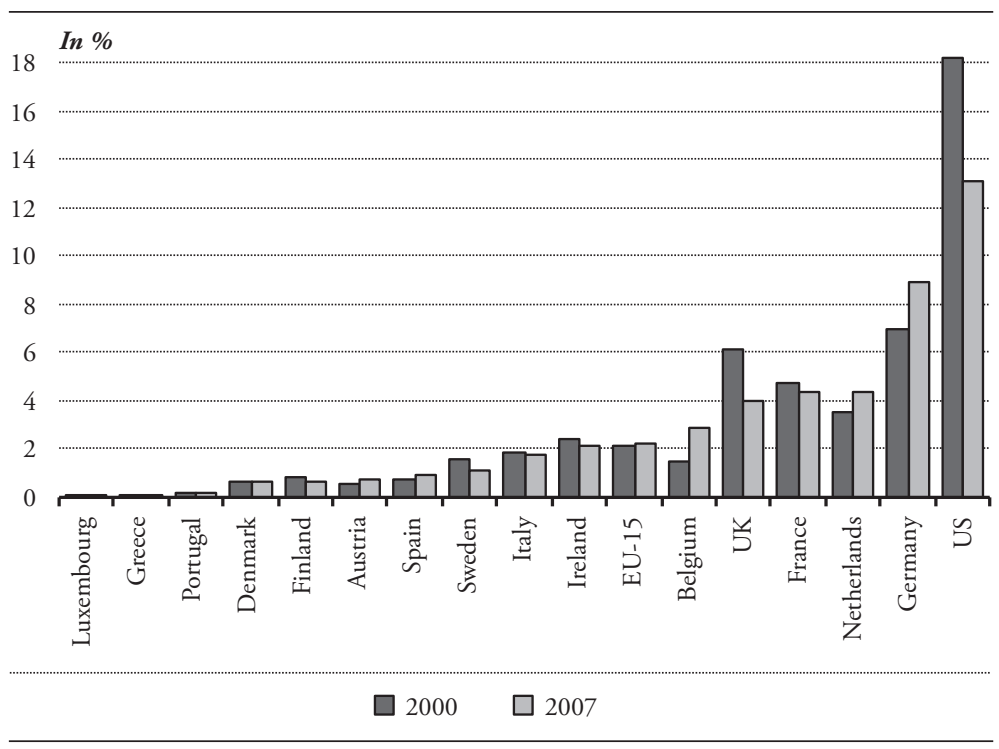

Source: Authors' elaboration based on OECD (2014a). 
On the contrary, in medium-high-tech sectors, the supremacy of Germany is confirmed by its higher and increasing market share in global trade during the 2000-2007 period, whereas the US has registered a declining share (see Figure 18). Interestingly, the UK, Italy, Belgium and France have export market shares of medium-high-tech manufacturing which are less than half of German's share.

Figure 18: Export Market Shares of Medium-high-tech Manufacturing Relative to the World

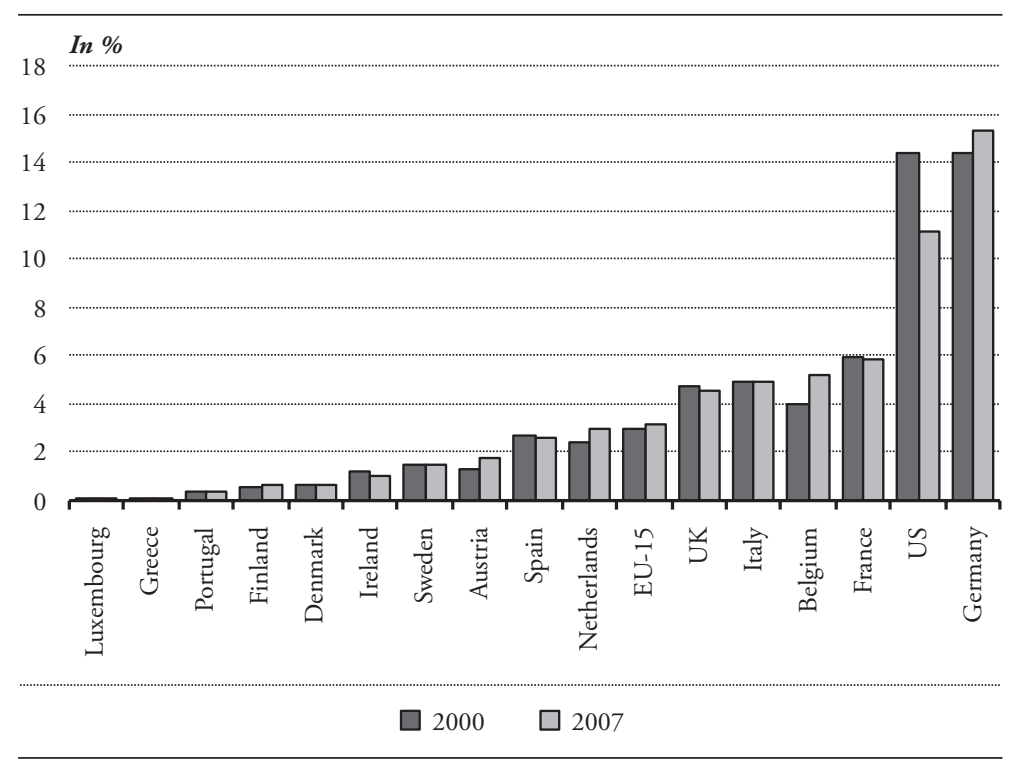

Source: Authors' elaboration based on OECD (2014a).

We also considered manufacturing export market shares classified into six broad categories (see Figure 19). The EU-15 during 2000-2008 has increased its export market shares in high, medium-high, low and particularly high and mediumhigh-tech sectors; these gains have been offset by losses in medium-low and ICTtech manufacturing sectors. 
Figure 19: Changes in Manufacturing Export Market Shares of EU-15 Relative to the World, by Subsectors, over the 2000-2008 Period

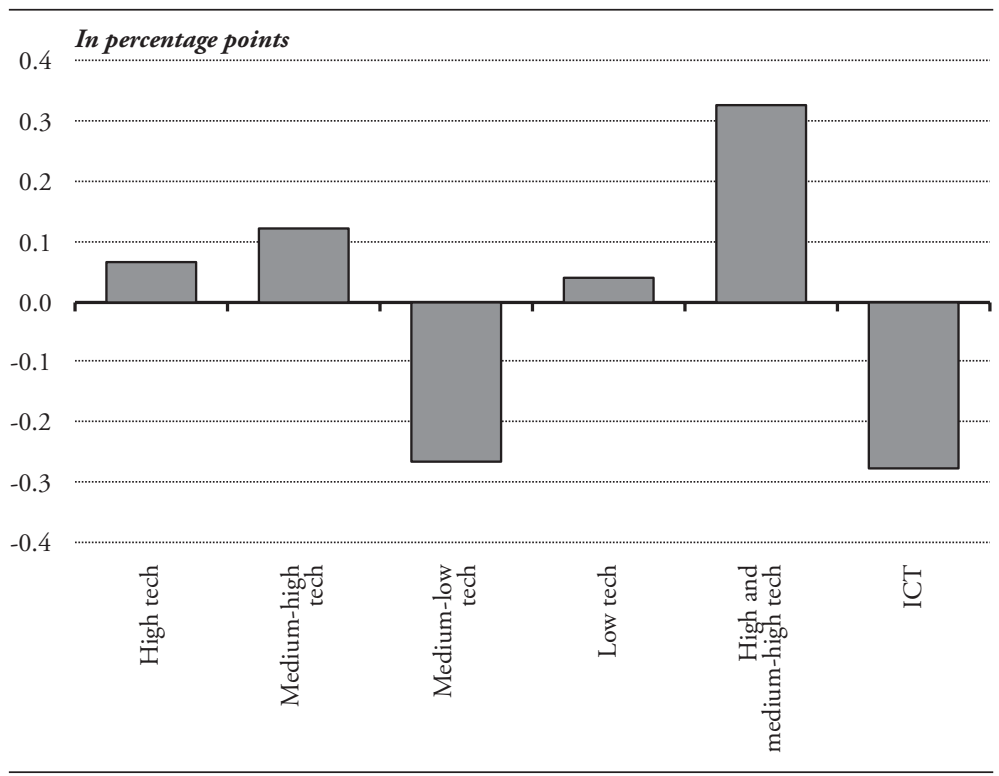

Source: Authors' elaboration based on OECD (2014a).

A clear illustration of enormous differences within the EU-15 is given by the comparison of Germany and Italy, the two European manufacturing leaders. During the 2000-2008 period, in two medium-tech sectors, chemicals and production of capital goods, OECD data confirm the increasing strength of Germany and the stable or declining position of Italy. Furthermore, Italy does not seem to have compensated its stagnant role in global trade in these mediumhigh-tech sectors by increasing its market shares in other medium-high-tech actvities. On the contrary, during the 2000-2008 period, Italy continued to be strongly specialized in medium-low and low-tech sectors, although exports of these sectors recorded a considerable decline. By contrast, over the same period, Germany showed increasing export market shares in all sectors, with the only 
exception of medium-low sectors. ${ }^{8}$ Interestingly, even the low-tech sectors recorded a considerable increase (OECD, 2014a).

Summing up, the decline in the shares of manufacturing employment and value added has occurred in a context of increasing globalization, that has led to boosts in export intensity, with manufacturing trade growing more rapidly than production. However, not all countries have benefited equally from this trend. Germany is undoubtedly one of the winners, given that it has increased its manufacturing export share and has narrowed the gap with respect to the US, that over the same period experienced just the contrary (a loss of its export market share). In high-tech sectors, however, Germany's catching-up process is far from complete. On the whole, EU-15 manufacturing export shares have remained stable, whereas G-7 and the OECD countries, on average, appear to be losers (see OECD, 2014a).

The EU-15, on average, maintains a comparative advantage in food, wood and paper products, chemicals, and to a lesser extent in production of capital goods. Furthermore, a reduction of medium-low and ICT export shares has taken place, and this has been offset by increases of high and medium-high sectors. In particular, Germany has gained a higher world share in medium-high-tech sectors: chemicals, machinery and equipment, and production of vehicles. In Italy, on the contrary, specialization processes in these sectors were generally more fragile. Italy's export performance reveals disappointing results, as is signalled by its export market shares - 4.46 percent in 2000 and 4.39 percent in 2008, respectively. Italy continues to have stronger specialization in medium-low and low-tech sectors.

The analysis therefore confirms the leading role in manufacturing of the US and Germany, but in different areas - in the production of high-tech, and medium-high-tech sectors, respectively. Furthermore, the comparison of the two

8 The medium-low-tech sectors include: manufacture of coke, refined petroleum products and nuclear fuels; manufacture of rubber and plastic products; basic metals and fabricated metal products; other non-metallic mineral products; building and repairing of ships and boats. 
traditionally major manufacturing economies, Germany and Italy, suggests an increasing polarization of EU countries between core and pheripheral economies.

As mentioned initially, our analysis covers only the pre-crisis period (until 2008). It ought to be noted, however, that the global crisis has had a very different impact on the manufacturing sector of individual EU members. There is a lot of diversity among countries and not all of them were able to recover quickly. According to the Competitiveness Report (European Commission, 2013), it is the countries that have maintained a large manufacturing base that have fared better, while the recovery has been driven mainly by exports of manufactures. After the global economic crisis, Germany improved its export record impressively, especially after 2010, recovering faster than other countries. It registered the highest increase in the share of manufacturing in 2010, when it occupied the leading position among EU-15, with a share of 20 percent of total value added.

\section{The Fundamental Role of Manufacturing Industry in the Western Balkans}

The ongoing analysis of trends in the EU is extremely relevant for the WB countries, not only because these countries are aspiring to join the EU. For a series of reasons linked to the structural features of the WB economies, manufacturing industry remains indispensable for economic growth and catching up with the more developed EU member states. Despite remarkable achievements in the WBs after 2000 - political and economic stabilization, strong growth (until 2009), fast trade liberalization, rapid trade recovery and increasing foreign direct investment (FDI) - the success story of the Central East European and Baltic (CEEB) countries from the 1990s has not been replicated a decade later in the WBs. ${ }^{9}$ For a series of specific reasons linked to the legacies of the 1990s, the WB economies were in a far worse situation in the early 2000s than were most CEEB countries in the early 1990s. Three groups of factors are primarily responsible for 
the delayed attainment of some transition objectives in the WBs: the political events of the 1990s that have also greatly contributed to economic instability; delayed integration with the EU and related exclusion of the WBs from main EU programs sustaining transition in Eastern Europe; and inappropriate economic policies, that have focused primarily on fast liberalization, macroeconomic stabilization and privatization, neglecting many other important microeconomic reforms (see Uvalic, 2012). While the third factor is common to both the WB and CEEB countries, the WBs missed the opportunity to draw lessons from the CEEB experience accumulated a decade earlier, thus ignoring the "postWashington consensus" formulated in the second half of the 1990s (Kolodko and Nuti, 1997).

It was expected that after years of isolation and stagnant or declining trade in the WB region, the acceleration of economic reforms after 2001 would ensure export-led growth, but this objective has not been effectively attained. During the 2000s, despite a fast increase in both exports and imports, the WB countries have had huge and, until 2009, continuously increasing trade deficits. Moreover, as economies they remain relatively closed and less integrated into the world economy than most CEEB countries. Strong GDP growth in the WB countries over the 2001-2008 period, rather than export-led, has mainly been based on growth of domestic demand stimulated by the rise in credit, wages and remittances. Today, weak export performance is the key structural deficiency of the WB economies, to a large extent due to limited restructuring of key industries that today are not competitive on world markets.

A comparison of the respective exports of goods and services/GDP ratios of the WBs and the CEEB countries reveals that WB countries have lower ratios than most CEEB countries (the only exceptions are Poland and Romania, as the largest countries) (see Figure 20). A variety of other indicators that are important for determining a country's competitiveness also indicate that the WBs are less competitive than the CEEB countries (see Figure 21 and Uvalic, 2013b). 
Figure 20: Exports of Goods and Services/GDP Ratios of the Western Balkan and CEEB Countries

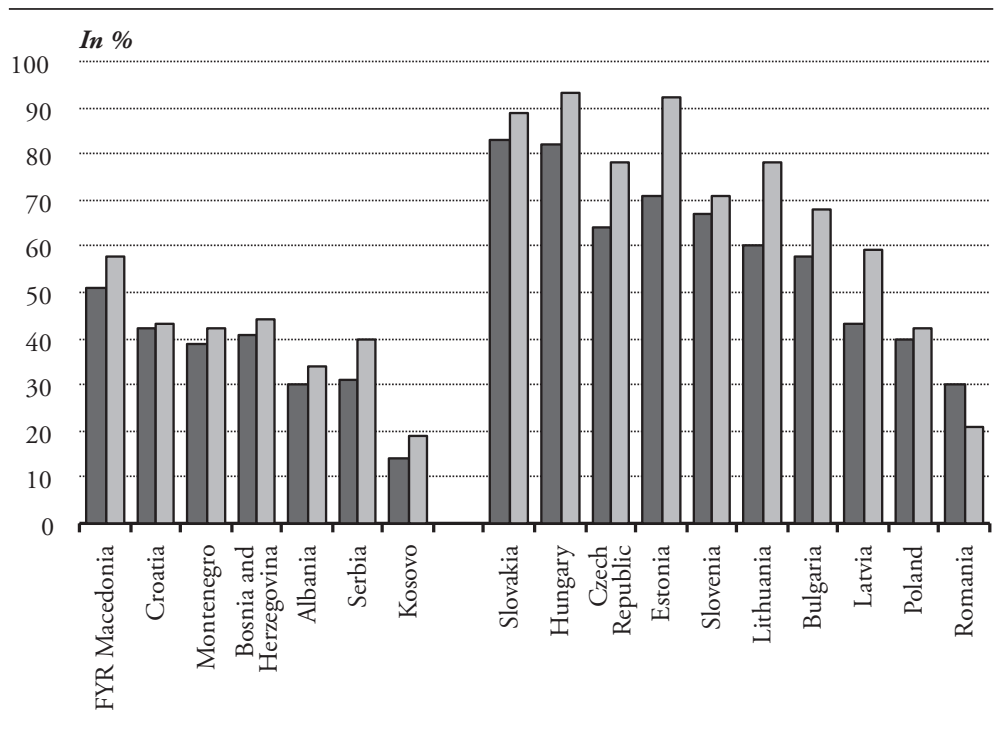

Source: Authors' elaboration based on the World Bank World Development Indicators (2014).

Unsatisfactory export performance derives primarily from supply-side factors and structural problems of the WB economies (Uvalic, 2013b). Three characteristics of the WB economies must be stressed in this regard: (1) the extreme process of deindustrialization since the early 1990s; (2) the inadequate volume and structure of FDI; and (3) structural changes in favor of fast growth of primarily non-tradable services.

(1) All the WB countries have undergone a very strong process of deindustrialization, more extreme than in CEEB. Many industrial sectors have not been modernized and restructured after the disintegration of Yugoslavia in 1991. During the 1990s, restructuring of many enterprises was postponed due to political instability that often caused delays in privatization and impeded the arrival of FDI. The process of deindustrialization was not only typical of the 
1990 s, as in other post-socialist economies, but it also continued in the 2000s in most countries. In Serbia, the tradable goods sector, consisting mainly of industrial goods and some agricultural products, has actually reduced its relative share from over 42 percent in 2001 to 24 percent in 2008 (Uvalic, 2010).

Figure 21: Overall Index and Subindexes of Global Competitiveness of the Western Balkan Countries, 2013-2014 (Rank/148 countries)

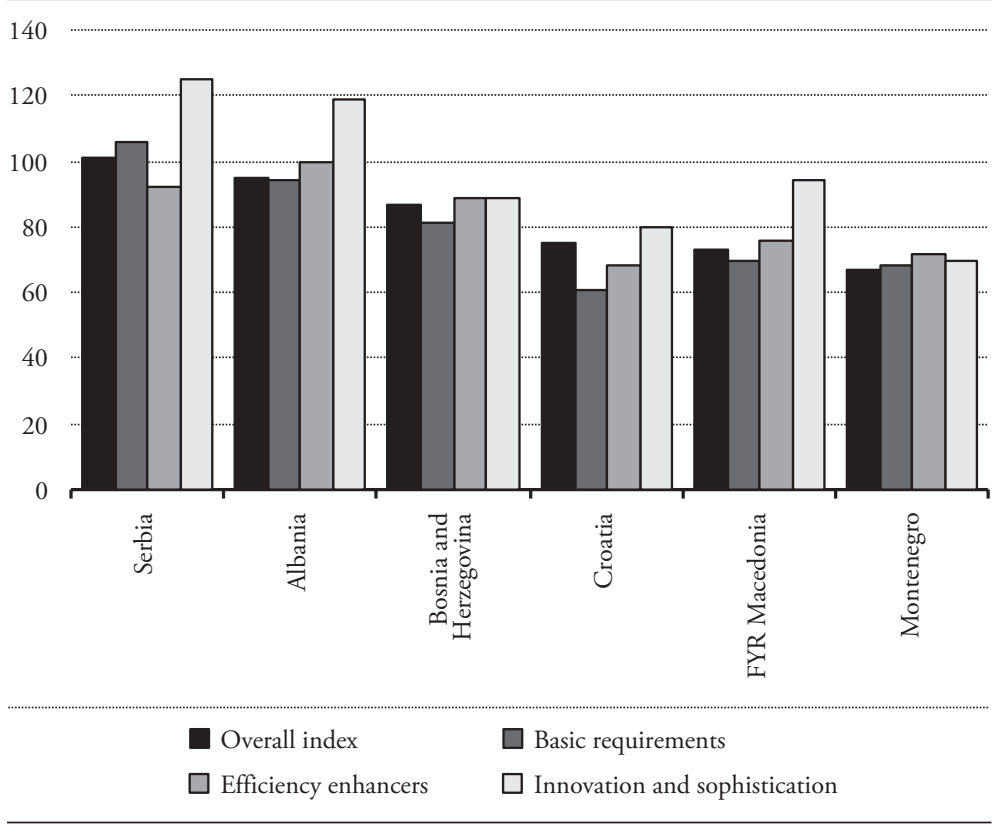

Source: Authors' elaboration based on World Economic Forum (2013).

A comparison of the WBs with the economically more advanced CEEB countries can again prove useful. In CEEB, after the strong collapse in the early 1990s, growth recovery was accompanied by improving trade balances (even surpluses) and in some countries by reindustrialization. This was not the case in the WB countries, where the process of deindustrialization and the decline in the relative importance of industry has, in most cases, continued also in the 2000s. Although there are no huge differences in the shares of industry value added of the CEEB 
and WB countries, some countries like Albania and Montenegro do have much lower shares (see Figure 22). The CEEB countries in 2008 generally had higher shares of industry value added than the WB countries, ranging from 29 percent to 38 percent of their respective GDPs.

In 2000, the two WB countries that had least suffered from the process of deindustrialization were FYR of Macedonia and Serbia, both having maintained industry value added shares in GDP of over 30 percent. FYR of Macedonia stands out as the most industrialized Balkan country, with a share of industry value added of 34 percent, similar to that of Slovenia or Poland. However, the only Balkan country that has registered a slight increase in the contribution of industry over the 2000-2008 period is Bosnia and Herzegovina (from 23 to 29 percent of GDP), while in all the other countries the shares have stagnated (Albania, Croatia, FYR of Macedonia) or declined (Montenegro, Serbia).

Figure 22: Industry Value Added in the WBs and the CEE Countries

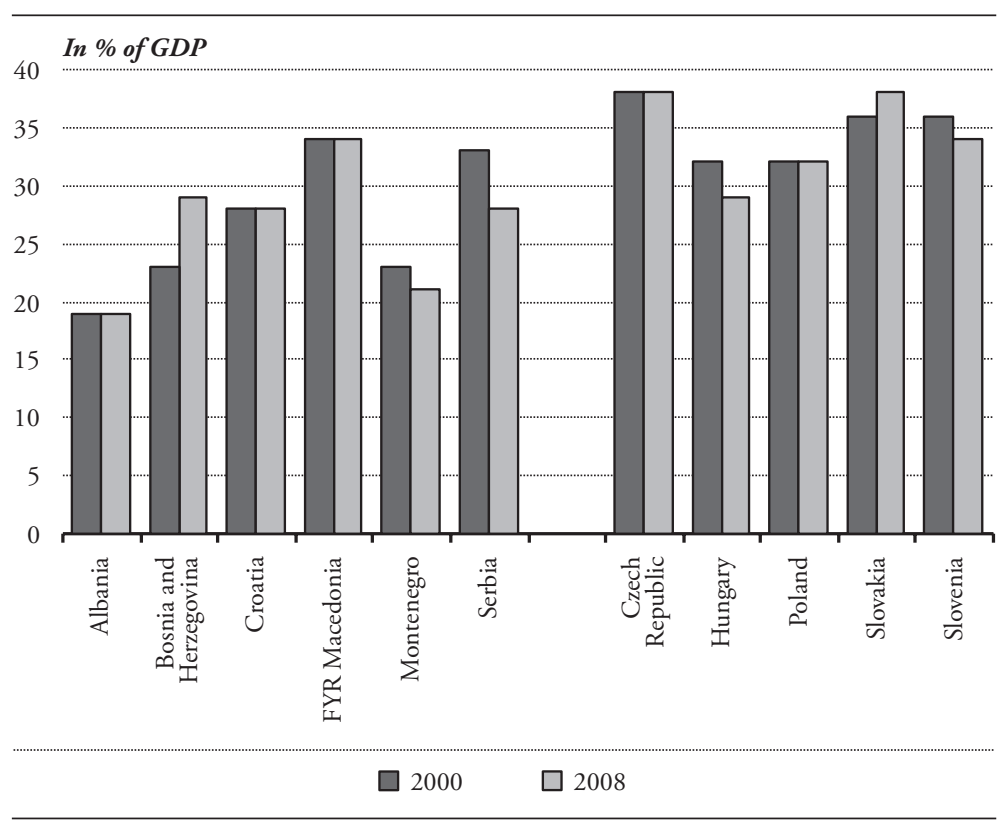

Source: Svejnar and Uvalic (2012) based on World Bank World Development Indicators (2014). 
If we look at more recent data on specifically manufacturing industry (thus excluding mining, construction, and electricity, gas and water supply), our conclusions about strong deindustrialization of the WB economies are grossly confirmed. Most WB countries registered a rather pronounced fall in manufacturing value added over the 2000-2012 period, to a very low share of GDP, ranging from 6 percent (Montenegro) to 16 percent (Albania, Croatia, Serbia) (see Figure 23). Only Albania and Bosnia and Herzegovina have experienced modest reindustrialization during the 2000s, but their shares of manufacturing value added still remain extremely low - in 2012, 16 percent and 12 percent of their respective GDPs - particularly considering their very low level of development (see below). Moreover, these WB shares are also extremely low if compared with shares of manufacturing value added in 2012 in some of the old EU member states (Germany - 21 percent, Finland - 19 percent, Italy - 17 percent), but also respective shares in the new EU member states (Czech Republic - 24 percent, Hungary - 23 percent, Slovak Republic - 21 percent, Slovenia - 21 percent, Poland - 19 percent) (World Bank, 2014).

(2) Specific features of Foreign Direct Investment (FDI) in WB countries have also contributed to insufficient recovery of manufacturing and unsatisfactory export growth. Most WB countries have attracted increasing FDI only after 2001, but inflows have been relatively low if compared to FDI in CEEB, the Community of Independent States, or even Bulgaria and Romania (Uvalic, 2010). FDI has not only arrived much later to the WBs than to the CEEB region but has had different characteristics (see Estrin and Uvalic, 2013). FDI was a key driver of economic growth in the CEEB countries, but in the WBs the composition of FDI has often not favored industrial restructuring. Manufacturing as the main sector for developing export potential was significant in the CEEB countries, but much less so in the WBs (see Becker et al., 2010). In CEEB many industries have been modernized thanks to investments by multinationals from Western Europe, while in the Balkans this has happened much less frequently (see Kalotay, 2010). The dominant part of FDI in the WBs has been in services, including banking, 
telecommunication, wholesale and retail trade and real estate, while relatively little has been invested in manufacturing industry (see Estrin and Uvalic, 2013). Due to such a structure of FDI, the Balkan countries have not been successful in integrating into global supply chains (Handjiski et al., 2010: 16).

Figure 23: Manufacturing industry value added in the WBs

$30 \stackrel{\text { In } \% \text { of GDP }}{ }$

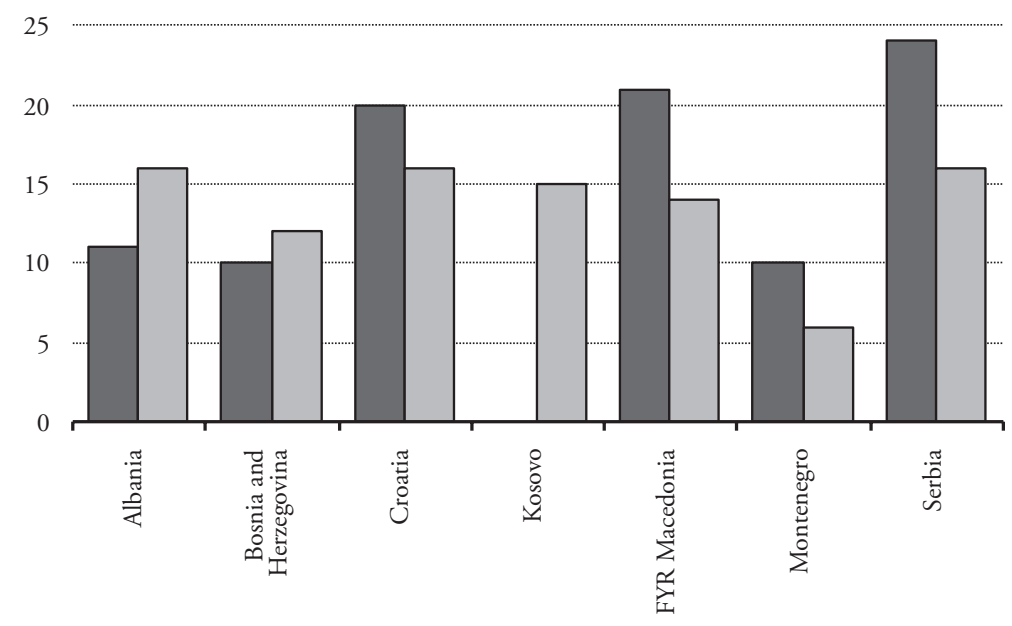

$2000 \square 2012$

Source: Authors' elaboration based on World Bank World Development Indicators (2014). 
Figure 24: Sectoral Composition of FDI in the Western Balkans

\section{In \% of total}

Albania

Inward FDI stock, 2010

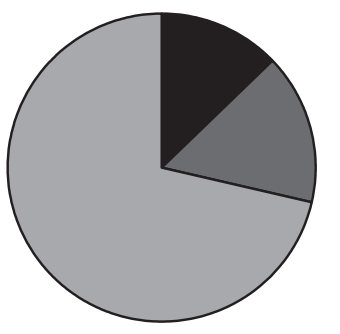

Primary

Manufacturing

$\square$ Services

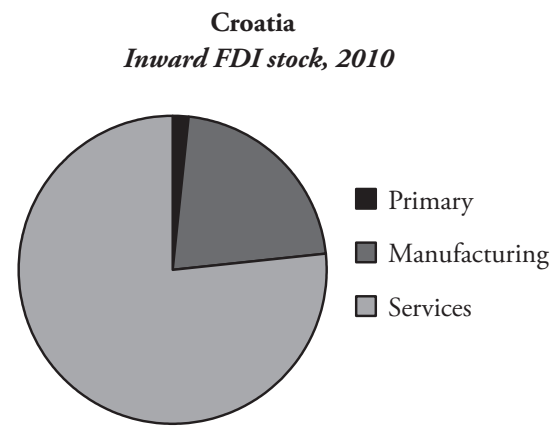

\section{Bosnia and Herzegovina}

Inward FDI stock, 2010

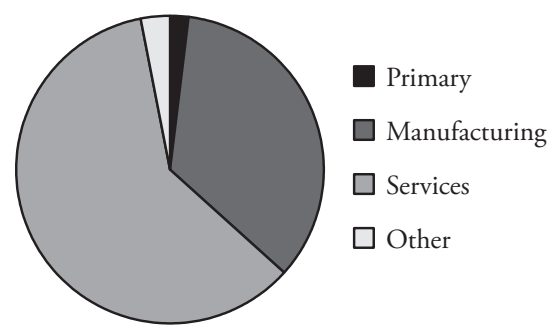

FYR Macedonia

Inward FDI stock, 2010

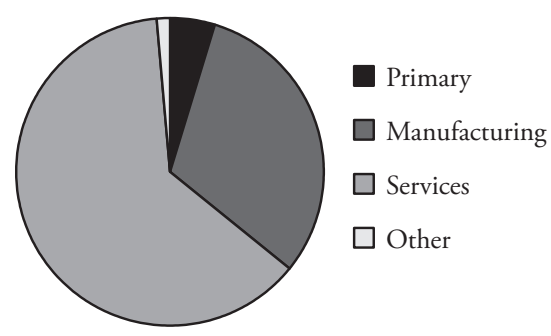

Serbia

Inward FDI stock, 2005-10

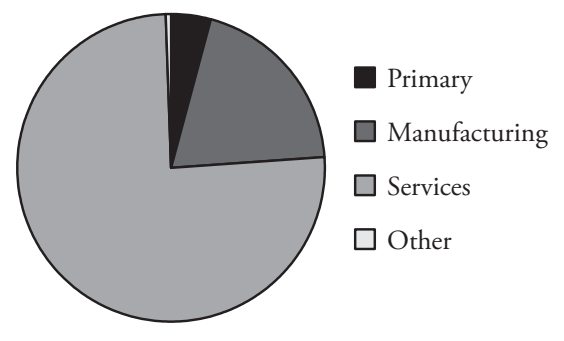

Source: Estrin and Uvalic (2013), based on WIIW data. 
Figure 25: GDP Per Capita (PPS) in the Western Balkan Countries

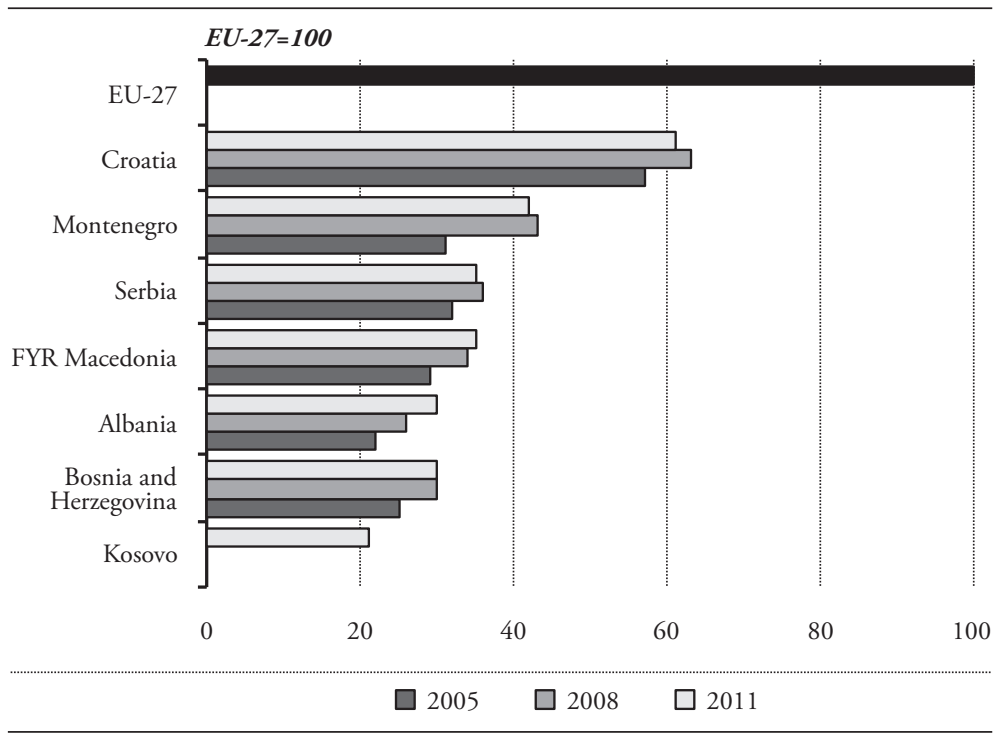

Source: Authors elaboration based on Eurostat (November 2012); also in Uvalic (2013a: 80).

(3) One of the consequences of the previous two characteristics is that structural changes in the WBs have brought a strong increase in services. Today the largest part of GDP, over 60 percent, in all WB countries, is produced in services telecommunications, trade, banking, real estate - which are non-exportable. The high GDP growth rates registered in 2001-2008 in the WBs were due to the fast expansion and high growth rates of services, much more than of manufacturing industry or agriculture. These changes also help explain why export performance of most WB countries has not been more impressive. The relatively high level of value added in services seems rather high, considering that the WB countries, all except Croatia, are still at a low level of development. In 2011, Croatia was the only one approaching 60 percent of the EU-27 average GDP per capita (at Purchasing Power Standards - PPS), while all the other countries had a GDP per capita ranging from 21 percent (Kosovo) to 40 percent (Montenegro) of the EU-27 average (see Figure 25). Slow industrial restructuring also contributed 
to limited economic recovery of 1989 GDP, since by 2008 three WB countries had still not reached the GDP level produced in 1989 - Serbia, Bosnia and Herzegovina and Montenegro (Uvalic, 2010: 258).

\section{What Policies for the Future?}

The global economic crisis from 2008 onwards has raised many questions regarding economic policies applied in both Western and Eastern Europe. Within the general debate, there has been a strong and renewed interest in industrial policy and reindustrialization, as evidenced in writings by Chang (2009), Rodrik (2008a, 2008b), Lin and Monga (2010) and others. Perhaps surprisingly, some of the traditional wisdom regarding the benefits of the off-shoring of production processes is also being questioned. The ongoing debate has been rather lively in some of the most developed EU member states as well, such as Italy, where manufacturing exports have been a driving force of fast economic growth during several decades of post-World War II development.

The European Commission has also proposed a somewhat different approach to industrial policy than the one that has dominated throughout the 2000s, namely an industrial policy sustaining certain industrial sectors that are regarded crucial for strengthening EU competitiveness. From a historical perspective, EU industrial policy has gradually evolved from the "vertical" approach that dominated in the 1970s based on various types of state subsidies to selected enterprises, towards a much more liberal approach, where industrial policy throughout the 2000s has mainly consisted of "horizontal" measures offered to all enterprises without discrimination, aimed at increasing enterprise competitiveness - such as supportive business environment, incentives for investing in $\mathrm{R} \& \mathrm{D}$, measures to support small and medium-sized enterprises, services for the creation of enterprise networks and technology parks, and cooperation between research institutions and industry (Bianchi and Labory, 2009). More recently, however, in a flagship initiative of the Europe 2020 strategy, the Commission emphasises 
not only horizontal measures but also the sector-specific dimension of industrial policy, identifying concrete sectors for development at a European level, such as space technology, clean and energy-efficient motor vehicles, environmental goods, energy supply industries, agro-food and business services (European Commission, 2010). In December 2012, the EU adopted a series of sector-specific measures that go in the direction of boosting technologically highly advanced and innovative knowledge-driven industries with key enabling technologies, such as nanoelectronics, advanced materials, industrial biotechnology, photonics, nanotechnology and advanced manufacturing systems, which would enable the EU to move along the global value chains (European Commission, 2012). This type of industrial policy is also at the basis of the EU's most recent initative aimed at increasing EU competitiveness through "knowledge-driven reindustrialization" (European Commission, 2013).

Within the broader discussions on the New Growth Model for Eastern Europe (see Nuti, 2009; Becker et al., 2010; Berglof, 2010), the model in the WB countries, in particular, is being reconsidered, since these countries have generally made less progress than the CEEB countries. It is interesting to note that the EU pro-competition industrial policies were adopted in almost all WB countries in the 2000s - state aid to industry was reduced, while horizontal and decentralized approaches to industrial policy have been replacing the older reliance on more direct vertical forms of industrial policy that had been designed to support key industries. The WB countries have implemented policies to support SMEs, develop technology parks, local industrial clusters and promote the transfer of knowledge from universities and research institutes to the business sector (see Bartlett, 2011). However, judging from the level of economic development of these countries today, their industrial diversification, structural changes and export growth, this type of policy has not substantially contributed to their economic recovery and catching up.

Measures for achieving export-led growth in the Balkan transition countries, that are proposed in some recent studies, will probably not be sufficient without 
deeper industrial restructuring and modernization. Part of the recent literature clearly stresses the importance of industrial policy in its various dimensions, encompassing not only horizontal measures to increase firms' competitiveness but also concrete government measures to support structural changes, industrial diversification and upgrading. Due to the strong decline in FDI from 2007 onwards, the WB countries will have to rely much more on their own resources to finance investment and growth. They will also need a more focused industrial policy, not to subsidize national champions but to encourage investment and faster industrial transformation. Industrial policy ought to be the key ingredient of the new development model in the WB countries, where some of the issues stressed in the recent literature on industrial policy could be useful (see Cerovic, Nojkovic and Uvalic, 2012).

Given that the global economic crisis has brought industrial policies back on the EU agenda, measures to support industrial development must also become a crucial component of the new approach to development in the WBs. The governments of the WB countries should implement a more targeted industrial policy to encourage investment, $R \& D$, and innovation both generally and in those sectors that are considered particularly important for the country's economic development. An important lesson for the WBs from the EU experience is that future drivers of industrial change might not be found in large old industries in traditional sectors, but in knowledge-driven and creative industries. Value added in industries with high knowledge, skills and technology intensity is much greater than in traditional industries.

At the same time, policy recommendations that stem from the EU experience, especially from the older member states, should take into account that different institutional contexts lead towards different outcomes of industrial policy, frequently determining the very success (or failure) of the chosen industrial policy. As shown by Acemoglu, Aghion and Zilibotti (2006), not only single policy institutions such as educational systems, trade and regulatory setting and R\&D policies, but also the interlocking complementarities within the 
institutional arrangements of the national innovation system may play a key role in the catching-up process. Thus, structural change in the WBs might depend on a whole set of policies and institutions that favor reallocation processes and remove the sources of inefficiency and economic backwardness (European Commission, 2013: 60).

The WB governments could draw on the EU experience to devise industrial policies that would be more efficient in sustaining industrial development, in the function of export-led growth and a faster process of catching-up. Being at one third of the EU-27 average level of development, the WB countries will probably be constrained, in most cases, to imitate the more developed countries, rather than to innovate. A concrete strategy could be to follow Lin and Monga's (2010) recommendation: namely, a country should look for its latent comparative advantage by targeting the mature industries in countries that are twice as developed.

If we look at the level of development of the WB countries, there are wide differences between the most and the least developed country, Croatia and Kosovo, but the remaining five countries have similar levels of development. If we exclude Croatia which is much more developed and is already an EU member, the latent comparative advantage of the other WB countries could be sought following the experiences in sectoral specialization of countries which are twice as developed. If we consider GNI per capita (at PPP) in 2009, Albania and Bosnia and Herzegovina could look up to sectoral specialization of Latvia and Lithuania (GNI of US\$ 16,700); Macedonia, Montenegro and Serbia, of Croatia (GNI of US\$ 19,040), Slovakia (GNI of US\$ 21,600) or the Czech Republic (US\$ 23,610); while Croatia could look up to countries such as Austria, Denmark or Sweden, which in 2009 all had a GNI per capita (at PPP) of around US\$ 38,000.

Industrial policy also ought to be considered at the regional level, through the creation of specific networks among the WB states. Although regional cooperation among the WBs has frequently been viewed with suspicion, these 
small countries can only gain from trans-national networks in the area of science, R\&D, technology, energy, infrastructure. In line with the long-term objectives in the EU, the WB countries also need a 2020 strategy that would create new employment opportunities, increase investment in R\&D, human capital and innovation. In the meantime, on 21 November 2013, such a 2020 Strategy for Southeast Europe has indeed been adopted by Ministers of all Southeast European countries at the conference of the Regional Cooperation Council in Sarajevo (see http://www.rcc.int), which suggests that these regional objectives will be carried further.

\section{Concluding Remarks}

In the aftermath of the global financial and economic crisis, industrial development has emerged as one of the key issues in the current debate on how to strengthen competitiveness of the EU. In reference to Eastern Europe, the discussions have focused on the New Growth Model. For the WB countries in particular, the policies applied so far ought to be reconsidered, since these countries have generally made less progress than the CEEB countries. However, measures that have been proposed for achieving faster economic development and raising competitiveness of the WB economies will probably not be sufficient without deeper industrial restructuring and modernization. The rich experience in industrial development in the EU member states could prove useful to the WBs.

The evolution and changes in the role of manufacturing industry in the EU clearly illustrate the main patterns of structural changes that have been similar across countries. However, there has also been an increasing differentiation among countries and these changes have not been unidirectional. The WB countries could draw on the experience of the more advanced EU members that have maintained a solid manufacturing base, in order to devise industrial policies and patterns of specialization that could strengthen their own manufacturing 
industries, promote export-led growth and accelerate economic development. Given that the WB economies are still relatively underdeveloped, devising such policies would benefit not only the WBs. The strenghtening of key industries could contribute to faster economic growth and the catching-up process, in this way reducing the future costs of accession of the WBs to the EU. Devising such industrial policies, therefore, should be a common goal that ought to be supported by EU programs presently aimed at helping WBs development efforts.

\section{Literature}

Acemoglu, Daron, Philipe Aghion and Fabrizio Zilibotti, 2006, "Distance to Frontier, Selection, and Economic Growth", Journal of the European Economic Association, 4(1), pp. 37-74. http://dx.doi.org/10.1162/jeea.2006.4.1.37

Bartelsman, Eric J., John C. Haltiwanger and Stefano Scarpetta, 2013, “CrossCountry Differences in Productivity: The Role of Allocation and Selection”, American Economic Review, 103(1), pp. 305-334. http://dx.doi.org/10.1257/ aer.103.1.305

Bartlett, Will, 2011, "Industrial policy, decentralization and growth in South East Europe", in Zlatan Reić and Vladimir Šimić, eds., Proceedings of the Ninth International Conference "Challenges of Europe: Growth and Competitiveness Reversing the Trends" pp. 33-53, Split: Faculty of Economics, University of Split.

Becker, Torbjörn, Daniel Daianu, Zsolt Darvas, Vladimir Glivorov, Michael Landesmann, Pavle Petrovic, Jean Pisani-Ferry, Dariusz Rosati, André Sapir and Beatrice Weder Di Mauro, 2010, Whither growth in central and eastern Europe? Policy lessons for an integrated Europe, XI, Brussels: Bruegel Blueprint Series.

Berglof, Erik, 2010, Transition Report 2010: Recovery and Reform, London: EBRD. 
Bianchi, Patrizio and Sandrine Labory, 2009, Le nuove politiche industriali dell'Unione Europea, Bologna: Il Mulino.

Bonatti, Luigi and Andrea Fracasso, 2013, "The German Model and the European Crisis”, Journal of Common Market Studies, 51(6). pp. 1023-1039. http://dx.doi. org $/ 10.1111 /$ jcms. 12067

Carlin, Wendy, 2012, "Real Exchange Rate Adjustment, Wage-Setting Institutions and Fiscal Stabilization Policies: Lessons from the Euro-Zone's First Decade”, CESifo Economic Studies, 59(3), pp. 489-519. http://dx.doi.org/10.1093/ cesifo/ifs 025

Cerovic, Bozidar, Aleksandra Nojkovic and Milica Uvalic, 2012, "Towards a new development model for the Balkans" in Tamara Backovic and Vesna Karadzic, eds., Economic Development and Institutional Organisation, 1, pp. 2149, Belgrade: Belgrade University - Faculty of Economics: Cugura Print.

Chang, Ha-Joon, 2009, "Industrial Policy: Can We Go Beyond an Unproductive Confrontation?", paper presented at the "Annual World Bank Conference on Development Economics”, Seoul, South Korea, June 22-24.

Coricelli, Fabrizio and Andreas Wörgötter, 2012, "Structural Change and the Current Account: The Case of Germany”, OECD Economics Department Working Paper, No. 940, February, Paris: OECD.

Estrin, Saul and Milica Uvalic, 2013, "Foreign direct investment into transition economies: Are the Balkans different?", Europe in Question Discussion Paper Series, No. 65, July, London: LSE.

European Commission, 2010, "An Integrated Industrial Policy for the Globalization Era: Putting Competitiveness and Sustainability at Centre Stage", No. 614, Brussels: European Commission.

European Commission, 2012, "A Stronger European Industry for Growth and Economic Recovery”, No. 582, Brussels: European Commission. 
European Commission, 2013, European Competitiveness Report 2013. Towards Knowledge Driven Reindustrialization, Commission Staff Working Document SWD No. 347 final, Brussels: European Commission. http://dx.doi. org/10.2769/87984

Handjiski, Borko, Robert Lucas, Philip Martin and Selen Sarisoy Guerin, 2010, "Enhancing Regional Trade Integration in Southeast Europe", World Bank Working paper No. 185, Washington DC: The World Bank.

Kalotay, Kalman, 2010, Patterns of inward FDI in economics in transition, Eastern Journal of European Studies, I(2), pp. 55-76.

Kolodko, W. Grzegorz and Domenico Mario Nuti, 1997, “The Polish Alternative - Old Myths, Hard Facts and New Strategies in the Successful Polish Economic Transformation", UNU / Wider Research for Action series, No. 33, Helsinki: World Institute for Development Economics Research.

Lin, Justin Yifu and Célestin Monga, 2010, "Growth identification and facilitation. The role of the state in the dynamics of structural change", The World Bank Policy Research Working Paper, No. 5313, Washington DC: The World Bank.

Nicoletti, Giuseppe and Stefano Scarpetta, 2003, "Regulation, productivity and growth: OECD evidence", Economic Policy, 18(36), pp. 9-72. http://dx.doi. org/10.1111/1468-0327.00102

Nuti, Domenico Mario, 2009, "The impact of the global crisis on transition economies", Economic Annals, LIV(81) pp. 7-20.

OECD, 2014a, Stan Archives, Stan Indicators, http://stats.oecd.org/ (accessed March 10, 2014).

OECD, 2014b, Stan Archives, OECD-WTO, Trade in Value Added (TiVA), http://stats.oecd.org/ (accessed March 10, 2014). 
Pilat, Dirk, Agnès Cimper, Krsten B. Olsen and Colin Webb, 2006, "The changing nature of manufacturing in OECD economies", Science, Technology and Industry Working Paper, No. 9, October, Paris: OECD.

Regional Cooperation Council, Sarajevo, http://www.rcc.int (accessed March 10, 2014).

Rodrik, Dani, 2008a, "The real exchange rate and economic growth", Brookings Papers on Economic Activity, 39(2), pp. 365-439.

Rodrik, Dani, 2008b, “Industrial policy: Don't ask why, ask how”, Middle East Development Journal, 1(1), pp. 1-29. http://dx.doi.org/10.1142/ S1793812009000024

Svejnar, Jan and Milica Uvalic, 2012, "Why development patterns differ: the Czech and Serbian models compared" in Masahiko Aoki, Timur Kuran and Gérard Roland, eds., Institutions and Comparative Economic Development, pp. 184-21, Basingstoke: Palgrave Macmillan.

Uvalic, Milica, 2010, Serbia's Transition. Towards a Better Future, Basingstoke: Palgrave Macmillan. http://dx.doi.org/10.1057/9780230281745

Uvalic, Milica, 2012, "Transition in Southeast Europe: Understanding Economic Development and Institutional Change" in Gérard Roland, ed., Economies in Transition: The Long-Run View, pp. 364-399, Basingstoke: Palgrave Macmillan.

Uvalic, Milica, 2013a, "The economic development of the Western Balkans since Thessaloniki" in Eviola Prifti, ed., The European Future of the Western Balkans. Thessaloniki@10 (2003-2013),pp. 73-82, Paris: European Union Institute for Security Studies. 
Uvalic, Milica, 2013b, "How to raise competitiveness of the Western Balkan economies?", paper prepared for the EACES Workshop "Competitiveness of Firms, Industries and Countries - Cause and Solution of European Crises" organized by the Faculty of Economics, University of Belgrade, Belgrade, September 20-21.

Veugelers, Reinhilde, ed., 2013, Manufacturing Europe's Future, XXI, Brussels: Bruegel Blueprint Series.

World Bank, 2014, World Development Indicators, http://data.worldbank.org/ data-catalog/world-development-indicators (accessed March 10, 2014 ).

World Economic Forum, 2013, The Global Competitiveness Report 2013-14, Geneve: World Economic Forum. 